\title{
Rajakarjalaismurteiden kielikontaktit venäläiskopioiden taajuuden ja fonologian valossa
}

\author{
SUSANNA TAVI \\ Itä-Suomen yliopisto
}

Tiivistelmä. Tämä korpuspohjainen kielikontaktitutkimus käsittelee venäjän kielen mallin mukaisten ainesten (Lars Johansonin termillä: "kopioiden") taajuutta ja fonologisia piirteitä Suomessa puhutuissa rajakarjalaismurteissa, jotka jakautuvat kuuteen pitäjänmurteeseen. Tutkimuksen aineistona on 1960- ja 1970-lukujen murrehaastatteluista koostuva synkroninen Raja-Karjalan korpus. Raja-Karjalan etelä- ja livvinkarjalaiset murteet ovat muusta karjalasta poiketen olleet intensiivisessä kontaktissa suomen kieleen osin jo 1600-luvulta alkaen ja viimeistään vuonna 1944 alkaneena siirtokarjalaisaikana. Suomen kielen oletetaan vaikuttaneen karjalalle tyypillisen venäläisperäisen sanaston käyttöön. Tutkimuskohteena ovatkin sellaiset venäläiskopiot, jollaisia ei esiinny suomen kielessä. Tilastolliset testit osoittivat, että erot venäläiskopioiden taajuuksissa pitäjänmurteissa ovat tilastollisesti merkitsevät: eniten venäläiskopioita on itäisimmässä ja vähiten läntisimmässä pitäjänmurteessa, vaikka informantit eivät ole asuneet alkuperäisillä puhuma-alueilla yli 20 vuoteen. Tulos vahvistaa leksikon osalta yleisitämerensuomalaisen hypoteesin, jonka mukaan venäjän vaikutuksen voimakkuus on jatkumon kaltaista lännestä itään. Myös fonologisen analyysin tulokset noudattelevat tällaista jatkumoa: suomen kielen fonotaksiin kuulumattomia konsonantteja esiintyi eniten itäisimmässä ja vähiten läntisimmässä pitäjänmurteessa. Sen sijaan vokaaleissa ei esiintynyt tällaista 
RAJAKARJALAISMURTEIDEN KIELIKONTAKTIT VENÄLÄISKOPIOIDEN ...

jatkumoa, mutta niiden laadussa on jälkiä kontaktista sekä venäjän pohjoismurteisiin että yleiskieleen.

Avainsanat: kontaktilingvistiikka; korpuslingvistiikka; kopioiminen; leksikko; fonologia; rajakarjalaismurteet; venäjä; suomi

\section{Johdanto}

Artikkelissa tarkastelen rajakarjalaismurteiden kielikontakteja suomeen ja venäjään venäläisperäisen sanaston ja sen fonologian näkökulmasta. Rajakarjalaismurteiden alue sijoittui suomen ja karjalan kielten puhumaalueiden rajalle (ks. kartta 1). Vuoden 1944 jälkeen alueen asukkaat joutuivat siirtymään pysyvästi muualle Suomeen. Raja-Karjalan murteiden ja siirtokarjalaisten puheen systemaattinen kielitieteellinen tutkimus on alkanut muun karjalan tutkimuksesta poiketen vasta 2000-luvulla (esim. FINKA; Kok 2016; Uusitupa ym. 2017; Uusitupa 2017; Sarhimaa 2017); tätä aiemmin on ilmestynyt vain yksittäisiä pitäjänmurrekuvauksia (esim. Kujola 1910, Turunen 1965). Aiempi tutkimuksen vähäisyys on johtunut rajakarjalaismurteissa esiintyvästä runsaasta etelä- ja livvinkarjalaisten piirteiden variaatiosta, joka on alkanut sittemmin kiinnostaa esimerkiksi dialektologeja ja kontaktilingvistejä.

Karjalan kieltä erottaa läheisestä sukukielestä suomesta vahva venäjän vaikutus. Karjalaan on omaksuttu venäjästä sanojen lisäksi äänteitä, morfeemeja ja syntaktisia rakenteita. Karjalasta taas on omaksuttu pohjoisvenäläisiin murteisiin sanastoa sekä prosodisia ja äännepiirteitä kuten sanapainon kiinteys sekä painollisen ensitavun vokaalin diftongiutuminen. Lisäksi karjalassa ja pohjoisvenäläisissä murteissa ilmenee yhteiskehitystä eli konvergenssia toisiaan kohti, minkä seurausta ovat esimerkiksi proteettiset sananalkuiset konsonantit ja soinnittomien klusiilien soinnillistuminen (Myznikova 2014: 33, 38-43, 46, 50-51, 65-69). Kielikontakti on ollut niin intensiivinen, että kielten rinnakkaiseloa voi kutsua jopa kieliliitoksi (Sarhimaa 1995: 216-217). Edellä mainittuja aineksia on myös rajakarjalaismurteissa, vaikka suomen vaikutus erottaakin niitä muusta karjalasta. 


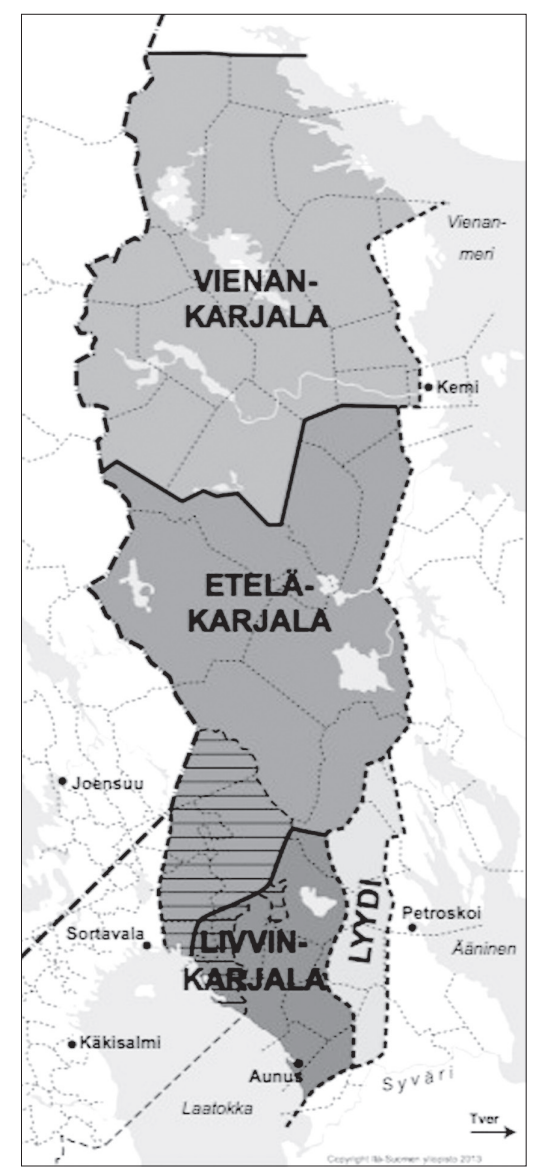

KARTTA 1. Rajakarjalaismurteiden puhuma-alue (viivoitettu)

Karjalan kielen venäläisperäisen sanaston etymologiaan keskittynyt tutkimus on alkanut jo 1700-luvulla (Ruoppila 1986: 7). Sittemmin karjalan venäläisiä lainoja ja tähän liittyviä fonologisia piirteitä ovat tutkineet esimerkiksi Heikki Ojansuu (1905; 1918), Jalo Kalima (1952), Raija Pyöli (1996) sekä Janne Saarikivi (2009), erityisesti rajakarjalaisten murteiden osalta esimerkiksi Joh. Kujola (1910), Aimo Turunen (1965) sekä Susanna Tavi (2015). Lisäksi Karjalan kielen sanakirjassa (KKS) on hyödynnetty Raja-Karjalan pitäien alueelta kerättyjä laajojakin sanalippukokoelmia.

Aiemmasta etymologisesta tutkimuksesta poiketen tarkastelen tässä tutkimuksessa venäläisperäisiä sanoja korpuspohjaisesti ja synkronisesti, puhutun aineiston perusteella. Sanavastineiden käsittelyssä hyödynnän tilastollista sekä fonologista analyysiä. Viittaan tarkasteltaviin leksikaalisiin aineksiin termeillä sana (yleisesti), sane (korpuksen esiintymät) ja lekseemi (perusmuotoinen sana, jonka esiintymiä saneet ovat). 
RAJAKARJALAISMURTEIDEN KIELIKONTAKTIT VENÄLÄISKOPIOIDEN ...

Perinteinen termi lainasana ei sovellu kyseessä olevaan tutkimusasetelmaan, koska termi viittaa etymologiseen tutkimukseen, ja on siten semanttisesti sopimaton kuvailemaan synkronista puhuttua kaksikielistä aineistoa. Sopivampi termi on kopio (engl. copy), joka viittaa siihen, että aines ei ole alkuperäinen aines lainassa vaan kopioitu versio, joka jää toiseen kieleen omaksi ainekseen; tämä termi kuuluu Lars Johansonin kehittämään "koodikopioimisen" kuvausmalliin (engl. codecopying framework; Johanson 2002: 261). Kopiot voivat olla globaaleja (engl. global copy), jolloin kopioituvan aineksen kaikki ominaisuudet kopioituvat raakalainojen tavoin mallikoodista (engl. model code; tässä venäjä sekä paikoin suomi) peruskoodiin (engl. basic code; tässä karjala ja etenkin rajakarjalaismurteet). Lisäksi kopiot voivat olla valikoivia (engl. selective copy), jolloin vain osa ominaisuuksista kopioituu kuten käännöslainoissa. (Johanson 2002: 261-265.) Jälkimmäisiä ei tarkastella tässä tutkimuksessa. Tarkasteltaviin kielimuotoihin viitataan koodi-termin lisäksi niiden omilla nimillä sekä termeillä idiolekti, murre, kieli ja varieteetti.

Tutkimus vastaa seuraaviin kysymyksiin: onko Raja-Karjalan kuuden pitäjänmurteen kesken eroja venäläiskopioiden määrässä ja fonologiassa, kuinka suomen kieli on vaikuttanut venäläiskopioiden fonologiaan ja mitä kopioiden fonologian perusteella voidaan päätellä rajakarjalaisten kontakteista venäjään. Hypoteesina on, että venäläisperäiset sanat suomalaistuvat sekä laadullisesti että määrällisesti. Tutkimus tuo karjalan kielen venäläisperäisen sanaston tutkimisen kentälle uutena Suomessa puhutun varieteetin tarkastelun sekä toteuttaa tuoretta teoreettis-metodologista lähestymistapaa. Tuloksia voi soveltaa Suomessa puhuttavan karjalan kehittämistyössä.

Artikkelin rakenne on seuraava: luvussa 2 esittelen Raja-Karjalan kielellistä taustaa ja luvussa 3 kuvaan tutkimusaineiston sekä -menetelmät. Neljännessä luvussa raportoin tilastollisen vertailun tulokset pitäjien välisistä eroista venäläiskopioiden taajuudessa. Luvuissa 5 ja 6 analysoin erikseen venäläiskopioiden vokaalien sekä konsonanttien edustumista. Artikkeli päättyy tutkimustulokset kokoavaan lukuun 7. 


\section{Raja-Karjalan lingvistinen tausta}

Karjalainen kulttuuri alkoi muovautua Laatokan ympäristössä 600-800-luvulla, ja karjalaisen heimon voi katsoa syntyneen 1000-luvulla alueen väestön kasvettua nopeasti (Hämynen 1994: 19-20; Saksa 1994: 42-43). Väestön kasvuun vaikutti slaavilainen ekspansio, kun esivenäjän puhujat liikkuivat vesistöjä pitkin pohjoiseen uusille asuinsijoille. Itämerensuomen ja esivenäjän kontaktit alkoivat 500-700-luvuilla. (Fortson 2010: 419-420.) Ensikontaktit olivat kopioituneiden kielenainesten perusteella rauhanomaiset ja tasavahvuiset (Sarhimaa 1995: 214-215). Kontaktin katsotaan vaikuttaneen sekä itämerensuomen kielimuotojen erkanemiseen että pohjoisvenäläisten murteiden lohkeamiseen esivenäjästä (Sarhimaa 1995: 194-195).

Laatokan alueen asukkaiden rauhanomainen elo päättyi 1300-luvulta alkaneisiin sotiin. Leskisen (1998: 356-357) mukaan itämerensuomen erilliskehitys olisi alkanut juuri noihin aikoihin, kun Ruotsin ja Novgorodin välinen Pähkinäsaaren rauha oli jakanut muinaiskarjalan puhumaalueen kahtia läntiseen ja itäiseen osaan (ensin mainitusta kehittyivät suomen kaakkoismurteet, jälkimmäisestä karjala ja inkeroinen). Muinaiskarjalan jatkajia ovat siis sekä suomen itämurteet että sisarkielet karjala, lyydi ja inkeroinen. Livvinkarjalan piirteiden voi katsoa syntyneen muinaiskarjalan kontaktista muinaisvepsään. (Sarhimaa 2017: 32.)

On arvioitu, että karjala ja suomen itämurteet olisivat eriytyneet viimeistään 1500-luvulla (Uusitupa ym. 2017: 83-84; myös Sarhimaa 2017: 38). Pian sen jälkeen 1600-luvulla alue muovautui kielellisesti uudelleen, kun Stolbovan rauhassa Käkisalmen länin, johon Raja-Karjalakin kuului, liitettiin Ruotsiin. Ruotsin valta toi muutoksia karjalaisten elämään etenkin suosimalla luterilaista uskoa, joka perinteisesti ortodoksiseen kirkkoon kuuluneelle karjalaisväestölle oli vieras. Merkittävät määrät ortodoksikarjalaisia muutti Sisä-Venäjälle Tveriin ja Novgorodiin saakka elääkseen entiseen tapaan. Heidän tilalleen taas muutti luterilaista väestöä erityisesti Savosta, ja Raja-Karjalan kielellinen ja kulttuurinen savolaistuminen sekä uskontoon pohjaava kaksikielistyminen 
alkoivat etenkin läntisemmissä pitäjissä kuten Ilomantsissa. (Uusitupa ym. 2017: 70, 84; Kuujo 1963: 79.) Rajakarjalaisten yhteys muihin karjalaisiin ja venäläisiin kuitenkin säilyi, kun 1800-luvun alussa Suomen suurruhtinaskunta liitettiin autonomiseksi osaksi Venäjää (Uusitupa ym. 2017: 71).

1900-luvun alkuvuosikymmenet muokkasivat karjalan kielen kehityksen suuntaa rajusti, ja tätä aikaa voikin pitää eräänlaisena käännekohtana. Venäjän yleiskieli oli 1700-luvulla kehittynyt keskivenäläisestä kielimuodosta (Cubberley 2002: 313-316), ja myös nuoren Neuvostoliiton kielipolitiikka suosi tätä yleiskieltä, joka alkoi vaikuttaa Venäjän puolella puhuttuun karjalaan yhä voimakkaammin. Monet karjalaiset alkoivat kaksikielistyä ja käyttää venäjää karjalan sijaan (Sarhimaa 1995: 216-217). Jo ennen Venäjän vallankumousta yleisvenäjä oli vaikuttanut myös rajakarjalaisten kieleen ortodoksisen kirkon ja sen ylläpitämien, väestön venäläistämiseen pyrkivien koulujen kautta (Pyöli 2013: 163-167). 1800-luvulta lähtien, kun kansallisuusaate oli Suomessakin nostattanut kiinnostusta Karjalaan, kouluopetuksen järjestäminen oli ollut tavallaan Suomen ja Venäjän tapa kilpailla Karjalasta (Uusitupa ym. 2017: 71-72).

KARTTA 2. Raja-Karjalan pitäjät, karjalankielinen alue merkitty harmaalla

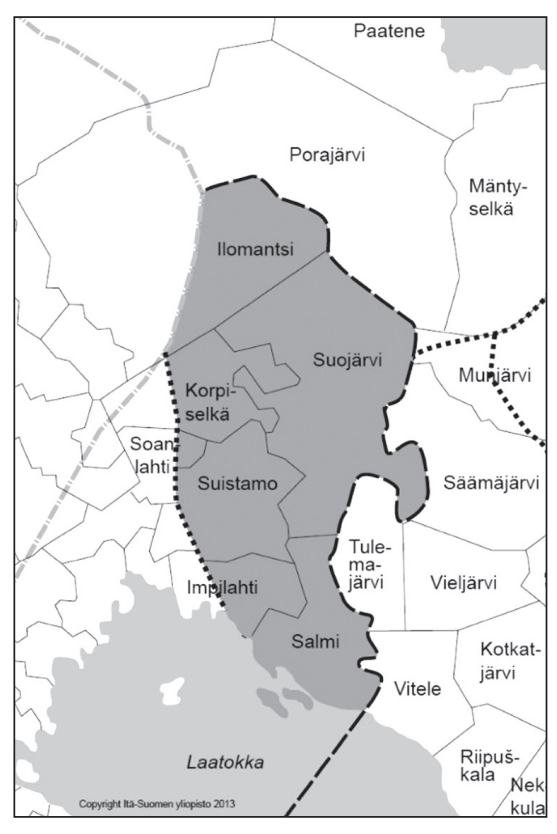


Rajakarjalaisten kontaktit muihin karjalaisiin ja venäläisiin katkesivat Suomen itsenäistyessä 1917. Lopullisesti rajakarjalaisten elämä mullistui vuonna 1944, kun Suomi luovutti Neuvostoliitolle jatkosodan päättäneessä Moskovan rauhassa itäpuolisista alueistaan muun muassa Raja-Karjalan. Raja-Karjalan asukkaat joutuivat siirtymään nykySuomen itä- ja pohjoisosiin, missä heihin kohdistui syrjintää sekä paine vaihtaa kieli suomeksi (Uusitupa ym. 2017: 72; Jeskanen 2005: 225).

Kielellisesti Raja-Karjalaan voi katsoa kuuluneen kuusi karjalankielistä pitäjää: Ilomantsin itäosat, Impilahti, Korpiselkä, Suistamo, Salmi ja Suojärvi (ks. kartta 2). Suomessa ja myös KKS:ssä käytetyn murrejaon mukaan murteet lomittuvat tällä alueella siten, että eteläkarjalaa puhuttiin Ilomantsissa ja Korpiselässä ja livvinkarjalaa Salmissa. Impilahdella, Suistamolla ja Suojärvellä puhuttiin molempia murteita. Raja-Karjalan alueella etelä- ja livvinkarjalan piirteitä tavattiin myös ikään kuin sekoittuneina. (Uusitupa ym. 2017: 67, 81.) Esimerkiksi Leskinen (1934: V-VI) on kuvaillut Raja-Karjalassa puhuttavaa karjalaa "Suomen-puoleisiksi sekamurteiksi", ja sittemmin on käytetty myös termiä rajamurteet (Uusitupa ym. 2017: 96-98). Rajakarjalaismurteiden kielelliset piirteet ovat kuitenkin yleiskarjalaisia, mikä vahvistaa edellä esitettyä kuvaa pitkästä rajanylisestä yhteiskehityksestä. Muusta karjalasta rajakarjalaismurteita erottaa eri-ikäinen suomen vaikutus, joka ilmenee etenkin läntisimpien pitäjien (Ilomantsi, Impilahti, Korpiselkä, Suistamo) idiolekteissä. (Uusitupa ym. 2017: 84-84.)

\section{Aineisto ja menetelmät}

Tutkimusaineistona on Itä-Suomen yliopiston FINKA-hankkeessa valmistunut Raja-Karjalan korpus, joka on koottu Suomen kielen nauhoitearkiston (SKNA) 1960- ja 1970-lukujen murrehaastatteluista. SKNA:n murrehaastatteluista on valittu mukaan sellaisia idiolekteja, jotka voi määritellä karjalankielisiksi tai joissa on selviä jälkiä karjalan kielestä. Siten esimerkiksi Raja-Karjalan pitäjänmurteista Soanlahti on jäänyt korpuksen ulkopuolelle. Korpuksessa on puhuttua kieltä Raja-Karjalan 
kuudesta karjalankielisestä pitäjästä (ks. luku 2) 76 informantilta, jotka ovat syntyneet viiden vuosikymmenen aikana 1870-1910-luvuilla. Heistä 52 on naisia ja 24 miehiä. Kaikki informantit asuivat haastatteluajankohtana Itä- ja Pohjois-Suomessa alueilla, minne heidät oli siirtokarjalaisina sijoitettu.

Tutkimuksessa tarkastelen Raja-Karjalan korpuksen venäläiskopioita pitäjänmurteiden tasolla. Osa korpuksen venäläisperäisistä sanoista tunnetaan myös suomen kielessä, mutta tässä tutkitaan vain sellaista osaa rajakarjalaismurteiden venäläisperäisistä sanoista, joita ei esiinny suomessa. Lisäksi olen jättänyt aineiston ulkopuolelle erisnimet, juhlapyhien nimet ja venäjäksi puhutut jaksot kuten referoinnit ja laulut. Tutkimuksen tarkoituksena ei siis ole löytää uusia etymologioita vaan käsitellä sitä sanastoa, joka erottaa suomea ja karjalaa toisistaan, sekä nostaa esiin sellaiset venäläisperäiset sanat, jotka ovat säilyneet karjalan kielen mukaisina, vaikka ne olisivat voineet korvautua suomenkielisillä vastineillaan. Tällainen asetelma on joskus myös puheenaiheena murrehaastatteluissa (ks. esimerkki 1).

(1) Haastattelija: ja teilä sanottih oprasa eikä ikoni

Informantti: ei nii oprasaks sanottih oprasaks. se_ol' oprasa eij ikoniks enne. nyky(aikana vain_on, tämä ikoni tullut, mitä miehi’ oon kuullut. se_ol' oprasa aina, oprasanurkka. vie oprasanurkkah tuonne, muuta ja. se_ol' pöytä ol' oprasanurkassa kansa, mikä o- missä, syötih kaikki saki. (Ilomantsi, SKNA 13017: 1a.)

Tutkimus on korpuspohjainen, koska koko korpuksesta käydään ensiksi läpi rajauksen ehtoja vastaavat kopiot, minkä jälkeen niitä käsitellään kvantitatiivisesti ja kvalitatiivisesti (McEnery ym. 2006: 8). Tällaisessa asetelmassa tutkimus nojaa vahvasti teoreettiseen taustaansa (Gries \& Stefanowitsch 2006: 73). Korpuspohjaisuus tukee myös kontaktilingvistiikan käyttöpohjaista näkökulmaa (engl. usage-based approach), jossa suositaan aitoon kielenkäyttöön perustuvia aineistoja (ks. esim. Backus 2014).

Korpuksen materiaalin käsittelin siten, että kokosin jokaisesta haastattelusta informanttien puheenvuorot kuuteen erilliseen pitäjä- 
kohtaiseen korpukseen FINKA-hankkeessa työskennelleen Lauri Tavin Puhujittain korpukseksi -skriptillä. Skripti haki Praat-ohjelmalla (Boersma \& Weenik 2017) kohdistetuista litteraatio- ja äänitiedostoista puhujien vuorojen litteraatiot ja muodosti niistä txt-muotoisen korpustiedoston, jokaisesta pitäjästä omansa. Näistä korpuksista muodostin sanalistat WordSmith Tools 6.0 -ohjelmalla (Scott 2012) ja kävin niistä käsin läpi kaikki rajauksen mukaiset venäläiskopiot. Muodostin vielä näistä sanoista erikseen omat pitäjäkohtaiset sanalistat ja laskin esiintymät pitäjittäin. Vertailin pitäjänmurteiden välisiä eroja tilastollisesti Pearsonin $\chi^{2}$-testillä saadakseni selville, ovatko erot myös tilastollisesti merkitseviä. Kaikki testit on tehty $R$-ohjelmalla (R Core Team 2016) ja sen fifer-paketin toiminnoilla (Fife 2017).

Fonologisessa analyysissä vokaalien tarkastelu on puhtaasti kvalitatiivista sanavastineiden vertailua, joka pohjaa venäjän sanapainoon. Vokaaliainesten vaihtelun tilastollinen testaaminen ei ole mielekästä, koska tähänastisen tutkimuksen perusteella vokaalien edustuksessa rajakarjalassa ei ilmene merkittävää suomen aiheuttamaa variaatiota (Tavi 2015: 58-59). Lisäksi venäjän liikkuvan sanapainon takia aina ei ole selvää, mistä venäjän sanamuodosta aines on kopioitu. Aiemman tutkimuksen perusteella konsonanteissa taas esiintyy selvästi suomen kielen aiheuttamaa kontaktilähtöistä variaatiota (Tavi 2015: 94), joten konsonanteista testataan tilastollisesti edellä mainitulla $\chi^{2}$-testillä eroja klusiilien soinnin sekä sibilanttien edustuksessa. Muutoin myös konsonanttien fonologinen analyysi on kvalitatiivinen.

\section{Raja-Karjalan korpuksen venäläiskopiot}

Korpuksessa on informanttien puhetta yhteensä 623485 sanetta, josta rajauksen mukaisia venäläiskopioita on 1,97 prosenttia eli yhteensä 12277 sanetta 496:sta eri lekseemistä. Venäläisperäisten saneiden taajuus on esitetty taulukossa 1 pitäjänmurteittain. Saneiden taajuus kuvaa venäläisvaikutuksen voimakkuutta ja pitäjien välisiä eroja siinä. Suuren taajuuden ajatellaan kertovan kopioitujen ainesten juurtuneisuudesta 
(Backus 2010: 239), ja siten tilastollisella analyysilla voidaan tukea päätelmiä, joita tehdään venäläisvaikutuksen voimakkuuden eroista eri pitäjien välillä. Pitäjien välisiä eroja ei myöskään ole mahdollista selvittää luotettavasti ilman tilastollista testaamista, koska otos- eli korpuskoot ovat erilaiset (ks. taulukkoa 1).

TAULUкко 1. Venäläiskopioiden frekvenssien suhteellinen osuus pitäjittäin Raja-Karjalan korpuksessa

\begin{tabular}{|l|c|c|c|}
\hline & $\begin{array}{c}\text { Kaikki korpuksen } \\
\text { saneet }\end{array}$ & $\begin{array}{c}\text { Venäläisperäiset } \\
\text { saneet }\end{array}$ & $\begin{array}{c}\text { Venäläisperäisten } \\
\text { saneiden osuus kaikista } \\
\text { esiintymistä (\%) }\end{array}$ \\
\hline Suojärvi & 56036 & 2766 & 4,94 \\
\hline Salmi & 52002 & 1702 & 3,27 \\
\hline Suistamo & 96622 & 2790 & 2,89 \\
\hline Korpiselkä & 167714 & 2936 & 1,75 \\
\hline Impilahti & 84948 & 1264 & 1,49 \\
\hline Ilomantsi & 166163 & 819 & 0,49 \\
\hline Yht. & 623485 & 12277 & 1,97 \\
\hline
\end{tabular}

Eroja venäläiskopioiden määrissä testasin tilastollisesti pitäjänmurteittain ensin Pearsonin $\chi^{2}$-testillä, jonka tulos oli tilastollisesti merkitsevä (p-arvo < 0,001). Post-hoc-testeissä (Bonferroni-korjaus) selvisi, että kaikkien pitäjien välillä on tilastollisesti merkitsevät erot $(\mathrm{p}<0,05)$. Venäläisvaikutus on siis vahvinta Suojärven ja heikointa Ilomantsin pitäjänmurteessa. On kuitenkin huomattava, että $\chi^{2}$-testissä informanttien venäläiskopioiden frekvenssit on "tasapäistetty" pitäjittäin.

Taulukossa 2 esitetään venäläiskopioiden taajuus pitäjäkorpuksissa sanaluokittain. Sanaluokkien väliset erot venäläisperäisten saneiden taajuuksissa kuvailevat hyvin puhuttua kieltä: vaikka venäläisperäisiä substantiivilekseemejä on aineistossa enemmän kuin esimerkiksi konjunktiolekseemejä, puheessa konjunktiot esiintyvät substantiiveja taajemmin (ks. myös Tavi 2015: 30-31). Tämä ilmenee myös asetelmasta 1 , jossa on pitäjäkorpusten kymmenen yleisintä venäläisperäistä sanetta. Hyödyntämäni sanaluokkajako noudattelee Ahtian (1938) karjalan 
kielioppia, jonka pohjana on Suojärven 1900-luvun alkuvuosikymmenten kieli. Partikkeleiksi luokiteltavat konjunktiot ja interjektiot olen erottanut ryhmästä havainnollistamisen vuoksi.

TAULUKко 2. Raja-Karjalan korpuksen venäläiskopioiden frekvenssit pitäjittäin ja sanaluokittain

\begin{tabular}{|l|c|r|r|r|r|r|r|}
\hline & $\begin{array}{c}\text { Subs- } \\
\text { tantiivi }\end{array}$ & $\begin{array}{c}\text { Adjek- } \\
\text { tiivi }\end{array}$ & Adverbi & Verbi & $\begin{array}{c}\text { Kon- } \\
\text { junktio }\end{array}$ & $\begin{array}{c}\text { Interjek- } \\
\text { tio }\end{array}$ & $\begin{array}{c}\text { Partik- } \\
\text { keli }\end{array}$ \\
\hline Suojärvi & 725 & 14 & 80 & 168 & 1418 & 296 & 65 \\
\hline Salmi & 478 & 4 & 18 & 55 & 801 & 275 & 71 \\
\hline Suistamo & 1031 & 11 & 8 & 157 & 1082 & 453 & 47 \\
\hline Korpiselkä & 1121 & 19 & 87 & 136 & 1320 & 249 & 4 \\
\hline Impilahti & 304 & 12 & 4 & 50 & 465 & 343 & 86 \\
\hline Ilomantsi & 510 & 4 & 0 & 38 & 195 & 70 & 2 \\
\hline Yht. & 4176 & 64 & 197 & 599 & 5280 & 1686 & 275 \\
\hline
\end{tabular}

Asetelmasta 1 ilmenee, että partikkelit, konjunktiot ja interjektiot ovat kaikissa pitäjänmurteissa yleisimpiä venäläisperäisiä saneita. Muutamat substantiivit ja verbit ulottuvat kymmenen yleisimmän venäläiskopion joukkoon, mutta fonologinen variaatio vaikuttaa siihen, että tällaiset saneet eivät saa suuria frekvenssilukuja.

\section{Vokaalien fonologinen analyysi}

\subsection{Rajakarjalan, suomen ja venäjän vokaalijärjestelmistä}

Venäjän kielessä on kuusi vokaalifoneemia, etiset $i$ ja $e$, keskivokaali $i$ (transkriptioissa $y$ ) ja takaiset $u$, o ja $a$ (Bondarko 2009: 23). Karjalassa ja suomessa taas on kahdeksan vokaalifoneemia: etiset vokaalit $i, e, \ddot{a}, y$ ja $\ddot{o}$ sekä takaiset $u$, $o$ ja $a$ (Iivonen 2009: 48). Venäjän ja karjalan vokaalijärjestelmät eroavat toisistaan siten, että venäjässä ei ole etisiä $a ̈-, y$ - ja $\ddot{o}$-vokaaleja ja että karjalassa ei ole keskivokaali i:tä. Lisäksi venäjässä ei ole vokaaliharmoniaa tai pituusoppositiota, paitsi pohjoisvenäläisten 
RAJAKARJALAISMURTEIDEN KIELIKONTAKTIT VENÄLÄISKOPIOIDEN ...

\begin{tabular}{|c|c|c|c|c|c|c|}
\hline Selite & Suojärvi & Salmi & Suistamo & Korpiselkä & Impilahti & Ilomantsi \\
\hline 1 sane & $d a$ & $d a$ & $d a$ & $d a$ & $a$ & $d a$ \\
\hline frekvenssi & 924 & 664 & 958 & 968 & 305 & 147 \\
\hline sanaluokka & konj & konj & konj & konj & interj & konj \\
\hline 2 sane & $a$ & $a$ & $a$ & $a$ & $d a$ & $a$ \\
\hline frekvenssi & 278 & 260 & 393 & 230 & 220 & 66 \\
\hline sanaluokka & interj & interj & interj & interj & konj & interj \\
\hline 3 sane & $d a i$ & ta & hot & $d \ddot{a}$ & ta & $i$ \\
\hline frekvenssi & 240 & 55 & 40 & 153 & 126 & 28 \\
\hline sanaluokka & konj & konj & konj & konj & konj & konj \\
\hline 4 sane & $i$ & libo & $d \ddot{a}$ & $i$ & $i$ & libo \\
\hline frekvenssi & 88 & 29 & 38 & 142 & 52 & 13 \\
\hline sanaluokka & konj & konj & konj & konj & konj & konj \\
\hline 5 sane & hot & n'imidä & davai & onnak & $n^{\prime}$ imidä & muamon \\
\hline frekvenssi & 45 & & 24 & 40 & & 12 \\
\hline sanaluokka & konj & partik & $\mathrm{v}$ & $\mathrm{adv}$ & partik & s \\
\hline 6 sane & libo & što & libo & libo & tak & muamo \\
\hline frekvenssi & 40 & 15 & 22 & 22 & 26 & 10 \\
\hline sanaluokka & konj & konj & konj & konj & interj & s \\
\hline 7 sane & ta & hos & tak & onnakko & $d \ddot{a}$ & laučalla \\
\hline frekvenssi & 32 & 14 & 22 & 19 & 22 & 5 \\
\hline sanaluokka & konj & konj & interj & $\mathrm{adv}$ & konj & s \\
\hline 8 sane & nimidä & nimidä & vot & ruan' $i$ & hot & patrulli \\
\hline frekvenssi & 23 & & 21 & 19 & 19 & 5 \\
\hline sanaluokka & partik & partik & interj & $\mathrm{v}$ & konj & s \\
\hline 9 sane & daa & vot & buabo & muamo & $d a a$ & päčin \\
\hline frekvenssi & 20 & 10 & 20 & 15 & 11 & 5 \\
\hline sanaluokka & konj & interj & s & s & konj & s \\
\hline \multirow{4}{*}{$\begin{array}{l}10 \text { sane } \\
\text { frekvenssi } \\
\text { sanaluokka }\end{array}$} & rodih & с̌иајuи & päčči & $d^{\prime}$ 'iäd'öt & vot & ruasni- \\
\hline & 17 & 8 & 15 & 11 & 11 & kassa \\
\hline & $\mathrm{v}$ & $\mathrm{s}$ & $\mathrm{s}$ & s & interj & 5 \\
\hline & & & & & & s \\
\hline
\end{tabular}

Asetelma 1. Pitäjänmurteiden kymmenen yleisintä venäläisperäistä sanetta sekä niiden frekvenssit ja sanaluokat 
murteiden Äänisen ryhmässä, jossa sitä tavataan itämerensuomen vaikutuksesta (Sarhimaa 1995: 214). Karjalassa taas vokaaliharmonia ei toteudu yhtä usein kuin suomessa. Esimerkiksi karjalan emmo on suomen yleiskielessä emme. Myös vokaalien pituudessa on eroja: karjalassa pitkinä esiintyvät yleensä vain $u, i$ ja $y$. Muut suomen yleiskieltä vastaavat pitkät vokaalit ovat diftongiutuneet, esimerkiksi sanan maa vastineena on moa tai mua. (Genetz 1884: 121; Ahtia 1938: 8.)

Venäläiskopioiden vokaalien näkökulmasta tärkein itämerensuomea ja venäjää erottava seikka on sanapaino. Suomessa ja karjalassa sanan pääpaino on ensitavulla (Ahtia 1938: 10), kun taas venäjän yleiskielessä ei ole kiinteää sanapainoa. Venäjässä paino voi siis olla eri tavuilla eri sanoissa, ja lisäksi sanapainon sijainti voi vaihdella yhden sanan eri taivutusmuodoissa. (Nikunlassi 2002: 89.) Esimerkiksi venäjässä nominatiivimuotoinen kol'có 'sormus' ääntyy /kal'co/, kun taas nominatiivin monikkomuoto kól'ca ääntyy /kol'cal. Raja-Karjalan korpuksessa sana esiintyy muodossa kolčča. Venäläiskopio voi siis olla peräisin myös jostain taivutusparadigman muusta muodosta kuin nominatiivista tai infinitiivistä (Kalima 1952: 46). Toisaalta taas venäjän pohjoismurteiden Äänisen ryhmän murteissa sanapaino on itämerensuomalaisen substraattivaikutuksen johdosta ensitavulla, minkä seurauksena myös kyseisen tavun vokaali edustuu pitkänä ja diftongiutuneena. Esimerkiksi yleisvenäjän odín 'yksi' ääntyy pohjoisvenäjässä [oad'in] (Myznikova 2014: 46; myös Sarhimaa 1995: 213).

\subsection{Paino ensitavulla}

Monien Raja-Karjalan korpuksen venäläiskopioiden painollisten ensitavujen vokaalit edustuvat karjalassa pitkinä. Venäjän ensitavun painollista lyhyttä $a$ :ta vastaavat rajakarjalaisaineistossa pitkään $a$ :han palautuvat $o a$ - tai $u a$-diftongit (2-3). Pitkän $a$ :n diftongiutuminen on tyypillinen piirre sekä karjalan kielessä että suomen itämurteissa, sillä muutos on tapahtunut jo muinaiskarjalassa (Rapola 1966: 348- 350). Karjalassa pitkän a:n diftongiedustus pätee koko sanaan, kun taas 
suomen itämurteissa pitkä $a$ voi diftongiutua vain ensitavussa (Ahtia 1938: 8). Lisäksi venäjän kielen alkuperäisen painollisen ensitavun $a$ edustuu pitkänä myös ja-alkuisissa aineksissa (4). Korpuksessa esiintyy suomen vaikutuksesta myös pitkä $a$ esimerkiksi läntisimmässä Ilomantsin pitäjänmurteessa (5).

(2) poarah (Ilomantsi, Korpiselkä) < ven. pára 'pari'

(3) kuaššua (Suojärvi, Salmi, Suistamo) < ven. káša 'puuro'

(4) juablukan (Suistamo), juablokkapuuloi (Impilahti) < ven. jábloko 'omena'

(5) praasn'ikka (Ilomantsi) < ven. prázdnik 'juhla'

Venäläiskopioiden painollisen ensitavun muutkin lyhyet vokaalit edustuvat usein pitkinä. Esimerkiksi jos alkuperäisessä venäjänkielisessä sanassa on $u$-foneemi painollisella ensitavulla, rajakarjalaisessa vastineessa on usein pitkä $u$ (6 ja 7).

(6) duumaicen (Suojärvi), duumaičin (Salmi), duumittii (Suistamo), duumittih (Korpiselkä), duumaičet (Impilahti), duumimma (Ilomantsi) $<$ ven. dúmat' 'ajatella'

(7) kruuga, kruugan (Suojärvi), puolikruukkakengie (Suistamo) < ven. krúg 'ympyrä'

Painollinen $e$ taas edustuu aineistossa yleensä $i e$-diftongina (8) tai lyhyenä e:nä (9), joista diftongiedustus on karjalan fonotaksille tyypillisempi. Myös venäjän konsonanttien liudennus voi edesauttaa diftongiutumista, ja näin samasta kopiosta samassa pitäjänmurteessa voi esiintyä kaksi erilaista varianttia (10). Tällaisissa saneissa voi siis esiintyä sekä liudennus että diftongiutuminen (10-11) tai liudennus ja lyhyt vokaali (11: toinen esimerkkisane). Venäjän sanojen painollisen ensitavun $o$-foneemi taas pääsääntöisesti edustuu ou-diftongina (12-13) ja keski- $i$ ui-diftongina (14).

(8) died'oi (Suistamo) < ven. déd 'isoisä

(9) d'engua (Salmi) < ven. d'én'ga 'raha'

(10) d'iäd'ö, diäd'ö (Korpiselkä) < d'ad'a 'setä' 
(11) d'ielo (Suojärvi, Salmi ja Suistamo), d'el'o (Korpiselkä), d'ieluo (Ilomantsi) < ven. délo 'asia'

(12) koufei (Suojärvi) < ven. kófe 'kahvi'

(13) koufta (Suojärvi) < ven. kófta 'villatakki'

(14) muila (Ilomantsi) < ven. mýlo 'saippua'

\begin{tabular}{ccc}
\hline Venäjässä & $>$ & Rajakarjalaismurteissa \\
$a ́$ & $>$ & $u a \sim o a \sim a a$ \\
$u ́$ & $>$ & $u u$ \\
$e ́$ & $>$ & $i e \sim{ }^{\prime} i e \sim{ }^{\prime} e$ \\
$o ́$ & $>$ & ou \\
$y ́$ & $>$ & ui \\
\hline
\end{tabular}

Asetelma 2. Painollisen ensitavun vokaalien edustuminen

Asetelmasta 2 käy tiivistetysti ilmi, että venäläiskopioiden painollisen ensitavun vokaali edustuu rajakarjalaisaineistossa sen pitkää varianttia vastaavana diftongina. Rajakarjalaisaineistossa ensitavujen painolliset vokaalit ovat siis säilyneet suomen kielen vaikutuksesta huolimatta enimmäkseen karjalaisina, mikä voi johtua piirteiden osittaisesta yhtäläisyydestä suomen itämurteiden kanssa. Venäjän konsonanttien liudennus voi edesauttaa diftongiutumista, mutta alkuperäinen painollinen vokaali voi edustua liudennuksen jäljessä myös lyhyenä. Kuten esimerkeistä kävi ilmi, painollisen ensitavun vokaalien edustuksessa ei ole juurikaan eroja itäisten ja läntisten pitäjien kesken.

\subsection{Paino jälkitavuilla}

Yleensä karjalaan venäjästä kopioidut sanat pyrkivät noudattamaan mahdollisimman pitkälti mallikoodin mukaista fonologista asua (Tavi 2015: 96). Venäjän painollisia jälkitavuja vastaakin rajakarjalaismurteissa yleensä sama lyhyt vokaali (15 ja 16). Poikkeuksena on venäjän $\dot{i}$, jolle ei ole vastinetta karjalassa. Tällöin sitä voi vastata toinen, keskivokaali (17). 
RAJAKARJALAISMURTEIDEN KIELIKONTAKTIT VENÄLÄISKOPIOIDEN ...

(15) studeni studen'i (Impilahti, Suistamo, Salmi) < ven. studén' 'lihahyytelö'

(16) četvert (Suojärvi) < ven. četvert' 'neljännes'

(17) namaster (Suojärvi) < ven. monastýr' 'luostari'

Painollisten jälkitavujen ympäristössä konsonantit voivat pidentyä vastaamaan itämerensuomen CVCCV-sanahahmoa, kuten yleisessä karjalan hirssiä merkitsevässä prossa-sanassa (KKS s.v. prossa). Sana on todennäköisesti peräisin venäjän $a$-loppuisesta monikon nominatiivimuodosta prosá, sillä sananloppuinen $u$ Salmin aineistossa (18) on livvinkarjalainen piirre ja sen vastine muussa karjalassa sekä suomessa olisi $a$.

(18) brossupiiruada (Salmi) < ven. prosá 'hirssi' [neutri, mon. nom.]

Painollisten jälkitavujen vokaalien mukautumisessa rajakarjalaismurteissa ei ole viitteitä suomen vaikutuksesta. Painollisten jälkitavujen vokaalit edustuvat lähes poikkeuksetta lyhyinä. Rajakarjalaismurteiden venäläiskopioissa ei siis tavata painollisten vokaalien pidentymistä karjalan fonotaksin mukaisilla painottomilla jälkitavuilla toisin kuin esimerkiksi tverinkarjalaisessa paikannimistössä (esim. Maksuatiha).

\subsection{Akanjen ja okanjen vaihtelu painottomilla tavuilla}

Venäjän painottomien tavujen vokaalien redusoitumisessa esiintyy murrevariaatiota, joka ilmenee myös rajakarjalaismurteiden venäläiskopioissa. Yleisvenäjän painottomien tavujen vokaalien redusoitumisilmiöihin kuuluu akanje, joka tarkoittaa $o$ - ja $a$-foneemien välisen eron neutraalistumista. Ensimmäisessä painoa edeltävässä tavussa kyseiset foneemit edustuvat [a]-äännettä lyhyempänä ja suppeampana [^]-äänteenä. Muissa tavuissa $a$ ja $o$ edustuvat $a: n$ ja $\dot{t}: n$ väliin sijoittuvana lyhyempänä ja heikompana puoliväljänä vokaalina. Esimerkiksi yksikön genetiivin muoto somá sanasta som 'monni' ääntyy [sımá]. (Nikunlassi 2002: 88.) Pohjoisvenäläisissä murteissa tavataan akanjen sijaan okanjeilmiö, jossa painottomien ja painollisten tavujen $o$ :t ääntyvät $o$ :na eivätkä 
siis redusoidu. Molemmilla ilmiöillä on arveltu olevan suomalais-ugrilainen alkuperä: akanjen on väitetty olevan mokšamordvalaista perua (tämän yhä kirjallisuudessa kiertävän väitteen on kumonnut jo Ravila 1973), kun taas itämerensuomen katsotaan vaikuttaneen okanjen säilymiseen pohjoisvenäläisissä murteissa (Myznikova 2014: 45).

Pyölin (1996: 193) livvinkarjalaisessa aineistossa pohjoisvenäläinen okanje-ääntämys, painottoman $o: n$ edustuminen $o: n a$, ilmenee uusissakin venäläiskopioissa. Samanlaista okanje-edustusta nähdään myös Raja-Karjalan korpuksessa (19-21).

(19) dorogoile (Suojärvi) < ven. doróga 'tie'

(20) gospodiloi (Suojärvi), hospoti (Ilomantsi) < ven. gospód' 'herra, jumala'

(21) rodii (Suojärvi) < ven. rodit' 'tuottaa, synnyttää, kantaa'

Okanje on kielikontaktien perusteella odotuksenmukaisempi Raja-Karjalan korpuksen venäläiskopioissa. Silti rajakarjalaismurteissa esiintyy myös yleisvenäjän akanjen mukaista edustusta (22-26). Nämä murrevariantit voivat myös vaihdella aineistossa (27).

(22) vezimal'ittu (Suojärvi), mal'ittu (Salmi), mal'itun (Suistamo), mal'tvon (Ilomantsi) < ven. molitva 'rukous'

(23) kassu (Salmi), kassanauhoi (Suistamo), kassoa (Korpiselkä) < ven. kosá 'palmikko; viikate, kynnäs'

(24) starožakse (Salmi) < ven. storóž 'vahti, vartija, vahtimestari'

(25) kravat' $t^{\prime} i$, kravat't'ii, gravatin ja gravattizeh (Salmi) < ven. krovát' 'sänky'

(26) kaššelin (Salmi) < ven. košél' 'tuohikontti'

(27) paravoi, paravoidu, parovoikse < ven. parovóe (súdno) 'höyry(laiva)'

\begin{tabular}{ccccc}
\hline Yleisvenäjässä & $\sim$ & $\begin{array}{c}\text { Pohjoisvenäläisissä } \\
\text { murteissa }\end{array}$ & $>$ & $\begin{array}{c}\text { Rajakarjalais- } \\
\text { murteissa }\end{array}$ \\
$a ́$ & $\sim$ & $a ́$ & $>$ & $a$ \\
$o ́$ & $\sim$ & $o ́$ & $>$ & $o$ \\
$a$ & $\sim$ & $a$ & $>$ & $a$ \\
$a$ & $\sim$ & $o$ & $>$ & $o \sim a$ \\
\hline
\end{tabular}

ASETElma 3. Painollisten ja painottomien tavujen a:n ja o:n edustus 
RAJAKARJALAISMURTEIDEN KIELIKONTAKTIT VENÄLÄISKOPIOIDEN ...

Venäjän akanje ja okanje vaihtelevat siis Raja-Karjalan korpuksen venäläisperäisissä sanoissa enimmäkseen lekseemeittäin asetelman 3 kuvaamalla tavalla. Venäjän yleiskielinen vaikutus ei kahden edellä käsitellyn vokaalien redusoitumisilmiön perusteella ole ulottunut läntisimpään pitäjänmurteeseen saakka, koska akanjen sisältäviä kopioita ei ole läntisimmästä pitäjästä Ilomantsista, toisin kuin esimerkiksi okanjen sisältäviä kopioita. Akanjen ja okanjen vaihtelusta voi näin tehdä päätelmiä siitä, mistä venäjän varieteetista kopiot ovat peräisin.

\subsection{Ikanje ja muita painottomien tavujen murrevariantteja}

Akanjen lisäksi yleisvenäjässä esiintyy painottomien tavujen redusoitumisilmiö ikanje, joka tarkoittaa $i-, e-, o$ - ja $a$-foneemien välisen eron neutraalistumista painottomissa tavuissa liudentuneen konsonantin jäljessä. Ikanje ei esiinny pohjoisvenäläisissä murteissa. Ikanjessa ensimmäisessä painoa edeltävässä tavussa mainitut foneemit edustuvat $i$-äänteenä ja muissa tavuissa ne edustuvat $i$ :n ja $e$ :n väliin sijoittuvana suppeana vokaalina. Esimerkiksi venäjän lesá 'metsät' [maskuliini, mon. nom.] ääntyy [l'isá]. (Nikunlassi 2002: 88.)

Raja-Karjalan korpuksessa alkuperäinen $a$ (j:n tai liudentuneen konsonantin jäljessä) voi edustua i:nä (28) tai e:nä (29). Lisäksi alkuperäinen $e$ voi edustua $i$ :nä (30). Näytteiden $28-30$ saneissa edustus voi olla nimenomaan ikanjen aiheuttamaa.

(28) nedäli n'edäli n'edäl' $i$ (kaikki pitäjät) < ven. nedelja 'viikko'

(29) puametti (Salmi, Korpiselkä) < ven. pamjat' 'muisti'

(30) svitiläksähä < ven. svetill' 'öljylampun sydän'

Venäjän murre- ja yleiskielisen variantin välillä voi olla muitakin eroja, jotka nekään eivät eroa selvästi ikanjen vaikutuksesta, mutta ilmenevät vaihteluna rajakarjalaisaineiston venäläiskopioissa. Esimerkiksi näytteen 31 saneissa kyse ei ole ikanjen aiheuttamasta ensitavun $i$-äänteestä, vaan venäjän i:llisen murrevariantin síncy vaikutuksesta (Kalima 1952: 159). Sama sane tosin esiintyy aineistossa myös e:llisenä (32). 
(31) sinčoissa (Suistamo), sinččo (Korpiselkä), sinčossa (Ilomantsi) < ven. senéc $\sim$ síncy 'eteinen, porstua'

(32) senčoin (Suojärvi), senččoi (Impilahti) < ven. senéc síncy 'eteinen, porstua'

Toinen rajakarjalaisaineiston venäläiskopioista ilmenevä venäjän murreja yleiskielisen variantin välinen ero on se, että pohjoisvenäläisissä murteissa yleisvenäjän $e$ voi korvautua $o: l l a$ (ks. esim. Orlova 1970). Tällainen korvautuminen on tosin itämerensuomen vaikutusta: itämerensuomen vokaaliharmonia on vaikuttanut siihen, että venäjän $e$ muuttuu $o:$ ksi painottomissa tavuissa (Myznikova 2014: 51). Tällainen pohjoisvenäläisissä murteissa tapahtunut muutos ilmenee kahdessa Suojärven aineiston saneessa (33 ja 34), mutta esimerkissä 34 o esiintyy ensitavussa.

(33) kožovnah (Suojärvi) < yleisven. kožévnja 'nahkurin verstas'

(34) odva (Suojärvi) < yleisven. edvá 'tuskin, juuri, töin tuskin, hädin tuskin'

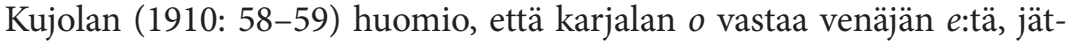
tää venäjän murrevariantit huomiotta, sillä itse asiassa odva-muoto (34) tavataan myös venäjän murteissa, joten $e>o$-muutos ei ole kopioitumisprosessissa tapahtuvaa korvautumista. Näin mallikoodin fonologinen asu on todellisuudessa lähempänä peruskoodin kopiota.

\begin{tabular}{|c|c|c|c|c|}
\hline Yleisvenäjässä & $\sim$ & $\begin{array}{c}\text { (Pohjois)venäläisissä } \\
\text { murteissa }\end{array}$ & $>$ & $\begin{array}{l}\text { Rajakarjalais- } \\
\text { murteissa }\end{array}$ \\
\hline ikanje & $\sim$ & ei ikanjea & $>$ & $\begin{array}{l}\text { ikanje tai muu } \\
\text { mukautuminen }\end{array}$ \\
\hline$e$ & $\sim$ & $i$ & $>$ & $i \sim e$ \\
\hline$e$ & $\sim$ & $o$ & $>$ & $o \sim e$ \\
\hline
\end{tabular}

ASETELMA 4. Venäjän painottomien vokaalien murrevariaatioiden edustus

Venäjän varieteetteihin perustuvat vokaaliedustukset on esitetty kokoavasti asetelmassa 4 . Nämä edustukset voivat siis auttaa kopioiden ikäämisessä niin karjalassa kuin koko itämerensuomessakin. Raja-Karjalan 
RAJAKARJALAISMURTEIDEN KIELIKONTAKTIT VENÄLÄISKOPIOIDEN ...

korpuksen synkronisen luonteen vuoksi diakronisten päätelmien teossa on kuitenkin oltava varovaisia: korpuksessa esiintyy venäläiskopioita, joiden vokaalien fonologia vastaa sekä venäjän yleiskielisiä että pohjoismurteisia variantteja. Voidaan päätellä, että Raja-Karjalan alueen karjalanpuhujilla on ollut jonkinlainen yhteys molempiin venäjän varieteetteihin.

\section{Konsonanttien fonologinen analyysi}

\subsection{Rajakarjalan, suomen ja venäjän konsonanttijärjestelmistä}

Karjalan ja suomen konsonanttijärjestelmät eroavat toisistaan etenkin siksi, että venäjä on vaikuttanut karjalan järjestelmään runsaasti. Venäjän vaikutusta ovat muun muassa sananalkuiset konsonanttiyhtymät sekä soinnilliset konsonantit $g, d, b, \check{s}, z, \check{z}$. (Sarhimaa 1995: 212; Turunen 1973: 84; 1965: 23; Myznikova 2014: 38.) Karjalaa ja suomea erottaa myös konsonanttien liudentuminen, jolla tosin voi olla sisäinen motivaatio - liudennusta esiintyy alkuperäisen $i$ :n edellä - mutta jota silti on pidetty venäläisperäisenä ilmiönä (Ojansuu 1905: 46; 1918: 83; Itkonen 1968: 102-103). Karjalan liudennus kuitenkin poikkeaa venäjästä siinä suhteessa, että karjalassa (tverinkarjalaisia murteita lukuun ottamatta) liudentua voivat vain dentaalikonsonantit. Venäläisperäisten äänteiden lisäksi eteläkarjalan murteen erottaa suomesta se, että sananalkuinen $j$ saattaa ääntyä liudentuneen d:n tavoin (Turunen 1965: 24). Aineistossa tällainen edustus ilmenee venäläisperäisissä saneissa esimerkiksi 'ainut'merkityksisessä lekseemissä (35). Samasta lekseemistä esiintyy aineistossa myös $j$-alkuisia mallikoodia vastaavia variantteja (36).

(35) d'ed'inöö (Suojärvi), d'ed'inöi (Korpiselkä), d'et'inöille (Impilahti) < ven. jedinyj 'ainut'

(36) jedin'öidy (Suojärvi), jediinöidy (Salmi), jed'iinoida (Suistamo), jedinöi (Korpiselkä), jediinöi (Impilahti) < ven. jedínyj 'ainut'

Edellä esitettyjä karjalan ja suomen eroja lukuun ottamatta konsonanttijärjestelmät ovat yhtenevät. 
Asetelmassa 5 taas on esitetty kokoavasti karjalan ja venäjän kielten konsonantit. Vain karjalaan kuuluvat foneemit on lihavoitu, ja vain venäjään kuuluvat väritetty harmaalla. Olennaista on, ettei kaikkia liudentuneita konsonantteja esiinny karjalassa ja että liudennuksella ei karjalassa yleensä ole merkitystä erottavaa tehtävää.

\begin{tabular}{|c|c|c|c|c|c|c|}
\hline & Labiaalit & $\begin{array}{l}\text { Labio- } \\
\text { dentaalit }\end{array}$ & Dentaalit & $\begin{array}{l}\text { Palato- } \\
\text { alveolaarit }\end{array}$ & $\begin{array}{l}\text { Pala- } \\
\text { taalit }\end{array}$ & Velaarit \\
\hline Klusiilit & $\mathrm{b}, \mathrm{b}^{\prime}, \mathrm{p}, \mathrm{p}^{\prime}$ & & $\mathrm{d}, \mathrm{d}^{\prime}, \mathrm{t}, \mathrm{t}^{\prime}$ & & & $\mathrm{g}, \mathrm{g}^{\prime}, \mathrm{k}, \mathrm{k}^{\prime}$ \\
\hline Affrikaatat & & & c & $\check{\mathbf{c}}, \check{c}^{\prime}$ & & \\
\hline Spirantit & & $\mathrm{v}, \mathrm{v}^{\prime}, \mathrm{f}, \mathrm{f}^{\prime}$ & & & $\mathrm{j}$ & $\mathrm{h}, \mathrm{h}^{\prime}$ \\
\hline Sibilantit & & & $\mathrm{Z}, \mathrm{z}^{\prime}, \mathrm{s}, \mathrm{s}^{\prime}$ & ž, š, šč́ & & \\
\hline Lateraalit & & & $1,1^{\prime}$ & & & \\
\hline Tremulantit & & & $\mathrm{r}, \mathrm{r}^{\prime}$ & & & \\
\hline Nasaalit & $\mathrm{m}, \mathrm{m}^{\prime}$ & & $\mathrm{n}, \mathrm{n}^{\prime}$ & & & n \\
\hline Puolivokaalit & & $\mathbf{v}$ & & $\mathbf{j}$ & & \\
\hline
\end{tabular}

Asetelma 5. Karjalan ja venäjän konsonantisto Bondarkoa (2009: 28), Iivosta (2009: 57) ja Kujolaa (1910: 5) mukaillen

Seuraava analyysi koskee vain klusiileja, affrikaattoja sekä sibilantteja, sillä niissä on eroja rajakarjalaismurteiden ja suomen kielen välillä.

\subsection{Soinnittomat klusiilit}

Raja-Karjalan murteissa venäläisperäisten sanojen soinnittomien klusiilien kopioitumisstrategiat riippuvat jonkin verran siitä, esiintyykö klusiili sanan ensimmäisenä äänteenä, ts. sanan absoluuttisessa alussa, vai sanan sisässä. Sanan alussa konsonantin edellä klusiilit voivat edustua alkuperäistä vastaavina (37 ja 38), soinnillistua (39) tai kadota (40). Sanan sisässä klusiilit säilyvät yleensä mallikoodin mukaisina (41), joskin astevaihtelu voi aiheuttaa klusiileissa muita muutoksia kuten geminoitumisen (42). 
RAJAKARJALAISMURTEIDEN KIELIKONTAKTIT VENÄLÄISKOPIOIDEN ...

(37) kolčat (Ilomantsi) < ven. kolcó 'sormus'

(38) tolmaičimma (Salmi) < ven. tolmačít' 'osata huonosti; puhua epäselvästi, solkata'

(39) bläššie (Suojärvi) < pl'asát' 'tanssia'

(40) vuassua $\sim$ vuassaa vuassoa (Suojärvi, Salmi, Ilomantsi) < ven. kvás 'kotikalja'

(41) suapkaks (Ilomantsi) < ven. šápka 'hattu'

(42) rieppuo (Suistamo) < ven. répa 'nauris'

Muutoksia tapahtuu siis eniten sananalkuisessa asemassa. Esimerkin 40 venäjän sana kvas '(koti)kalja' on mukautunut rajakarjalaisaineistossa muun karjalan (KKS s.v. voassa) tavoin siten, että alkuperäisen sananalkuisen konsonanttiyhtymän ensimmäinen jäsen $k$ on kadonnut, jolloin konsonanttiyhtymä on mukautunut alkuperäisen itämerensuomalaisen fonotaksin mukaiseksi eli yksinäiskonsonanttialkuiseksi (Rapola 1966: 12).

Toinen sananalkuinen muutos on soinnillistuminen. Esimerkiksi lekseemi proasniekka (KKS) on hyvä esimerkki sananalkuisen soinnittoman klusiilin säilymisen ja soinnillistumisen vaihtelusta. Vaihtelua voi esiintyä samalla puhujalla jopa yhden puheenvuoron aikana (43).

(43) ka meän kyläs piettii muuda eullun Jorum päivä piettii bruažnikka. ga ol' (t'ad'oi) Del'i kui män' Joruloi naimizii sit sem päivä tehtii, häipäivän n'imi pruaznikaks. Joruloi män' naimizii. muuda meil on Varbakyläs oli, sroičampäivä. da toine bruazniekku oli emämpäivä. Varbakyläs. sidä lähembäm meil_ei ollu bruaznikkoa. (Suojärvi, SKNA 3083: 2a.)

Klusiilien soinnillistuminen lienee pyrkimystä prestiisikielen eli venäjän ääntämykseen. Piirrettä voi kuvailla hyperkorrektiksi (Ojansuu 1918), vaikka se esiintyy myös pohjoisvenäläisissä murteissa (ks. luku 1). Aineistossa (ks. taulukkoa 3 ) useimmiten soinnillistuu $p$ etenkin sanan alussa (44-46), mutta soinnillistuminen voi koskea muitakin soinnittomia klusiileja ja myös sanan sisässä (47).

(44) blot'ina (Suistamo) < ven. plotína 'pato'

(45) brost' $i$ (Korpiselkä) < ven. prostí(te) 'anteeksi' 
(46) brostoi (Impilahti) < ven. prostój 'yksinkertainen'

(47) bogonniekka (Suistamo) < ven. pokójnik 'vainaja'

Lisäksi klusiileja lisätään hyperkorrektisti myös sananalkuisen $r$ - tai l-äänteen edelle. Venäjän sanaan ládan 'suitsutuspihka' on lisätty alkuun $g$ tai $k$, esimerkiksi gluadanoa (Suistamo) ja kluadanoa (Korpiselkä; mutta myös luatanoa), ja venäjän rádi 'tähden' edustuu Korpiselän aineistossa muodossa gruadi. Hyperkorrektia soinnillistumista sekä hyperkorrektin sananalkuisen konsonanttiyhtymän muodostumista esiintyy siis samanlaisessa ympäristössä eli sanan alussa $r$ - tai $l$-äännettä edeltävässä asemassa. Tyypillisintä on kuitenkin klusiilien säilyminen soinnittomina (taulukot 3 ja 4).

TAULUKKо 3. Vaihtelu soinnittomien klusiilien edustuksessa sanan alussa

\begin{tabular}{|l|l|l|l|l|l|l|l|l|l|}
\hline $\begin{array}{l}\text { Sananalkuisessa } \\
\text { asemassa }\end{array}$ & $k>k$ & $k>g$ & $k>0$ & $p>p$ & $p>b$ & $p>0$ & $t>t$ & $t>d$ & $\begin{array}{c}t>0 \\
\text { tai } \\
\text { muu }\end{array}$ \\
\hline
\end{tabular}

Konsonantin edellä

\begin{tabular}{|l|r|r|r|r|r|r|r|r|r|}
\hline Suojärvi & 9 & 2 & 5 & 54 & 46 & 2 & 1 & 2 & 0 \\
\hline Salmi & 4 & 0 & 30 & 43 & 9 & 2 & 2 & 0 & 0 \\
\hline Suistamo & 11 & 4 & 9 & 24 & 86 & 0 & 2 & 0 & 0 \\
\hline Korpiselkä & 8 & 6 & 6 & 69 & 5 & 32 & 14 & 0 & 0 \\
\hline Impilahti & 4 & 0 & 18 & 33 & 10 & 1 & 1 & 1 & 0 \\
\hline Ilomantsi & 2 & 0 & 0 & 25 & 10 & 27 & 1 & 0 & 0 \\
\hline Yht. & 38 & 12 & 68 & 248 & 166 & 64 & 21 & 3 & 0
\end{tabular}

Vokaalin edellä

\begin{tabular}{|l|r|r|r|r|r|r|r|r|l|}
\hline Suojärvi & 69 & 7 & 0 & 90 & 5 & 0 & 16 & 1 & 0 \\
\hline Salmi & 42 & 0 & 0 & 37 & 0 & 0 & 11 & 0 & 0 \\
\hline Suistamo & 94 & 1 & 0 & 162 & 10 & 0 & 1 & 1 & 5 \\
\hline Korpiselkä & 92 & 0 & 0 & 107 & 45 & 0 & 18 & 7 & 1 \\
\hline Impilahti & 44 & 0 & 0 & 44 & 1 & 0 & 34 & 0 & 0 \\
\hline Ilomantsi & 32 & 0 & 0 & 59 & 0 & 0 & 5 & 0 & 0 \\
\hline Yht. & 373 & 8 & 0 & 499 & 61 & 0 & 85 & 9 & 6 \\
\hline
\end{tabular}


RAJAKARJALAISMURTEIDEN KIELIKONTAKTIT VENÄLÄISKOPIOIDEN ...

TAULukко 4. Vaihtelu soinnittomien klusiilien edustuksessa sanansisäisessä asemassa

\begin{tabular}{|l|r|r|r|r|r|r|r|r|r|}
\hline $\begin{array}{l}\text { Sanansisäisessä } \\
\text { asemassa }\end{array}$ & $\boldsymbol{k}>\boldsymbol{k}$ & $\boldsymbol{k}>\boldsymbol{g}$ & $\boldsymbol{k}>\mathbf{0}$ & $\boldsymbol{p}>\boldsymbol{p}$ & $\boldsymbol{p}>\boldsymbol{b}$ & $\boldsymbol{p}>\mathbf{0}$ & $\boldsymbol{t}>\boldsymbol{t}$ & $\boldsymbol{t}>\boldsymbol{d}$ & $\begin{array}{c}\boldsymbol{t}>\mathbf{0} \text { tai } \\
\text { muu }\end{array}$ \\
\hline Suojärvi & 320 & 9 & 28 & 53 & 1 & 0 & 220 & 2 & 34 \\
\hline Salmi & 108 & 0 & 9 & 25 & 0 & 0 & 123 & 3 & 18 \\
\hline Suistamo & 302 & 3 & 28 & 42 & 1 & 1 & 273 & 3 & 26 \\
\hline Korpiselkä & 327 & 6 & 61 & 73 & 1 & 3 & 167 & 0 & 39 \\
\hline Impilahti & 93 & 2 & 3 & 19 & 0 & 0 & 93 & 2 & 6 \\
\hline Ilomantsi & 32 & 1 & 11 & 19 & 0 & 0 & 78 & 0 & 21 \\
\hline Yht. & 1182 & 21 & 140 & 231 & 3 & 4 & 954 & 10 & 144 \\
\hline
\end{tabular}

Selvittääkseni soinnittoman edustuksen variaatiota hyperkorrektin soinnillistumisen kanssa laskin taulukoiden 3 ja 4 kaikki soinnittomat ja sitten soinnilliset edustukset yhteen pitäjittäin. Testasin pitäjien välisiä eroja soinnittomien klusiilien edustuksessa Pearsonin $\chi^{2}$-testillä, jonka tulos oli tilastollisesti merkitsevä ( $\mathrm{p}<0,001)$. Bonferroni-korjatussa post hoc -ristiinvertailussa paljastui, että Suojärven ja Ilomantsin, Suistamon ja Ilomantsin, Korpiselän ja Impilahden sekä Impilahden ja Ilomantsin välillä on tilastollisesti merkitsevät erot $(\mathrm{p}<0,05)$. Muiden mahdollisten pitäjäparien välillä ei ollut eroa. Tämä tarkoittaa, että soinnittomien klusiilien edustuksen vaihtelu nousee merkitseväksi lähinnä itäisimpien ja läntisimpien pitäjien välillä, mikä tukee variaation kontaktilähtöisyyttä.

\subsection{Soinnilliset klusiilit}

Raja-Karjalan korpuksen venäläiskopioiden alkuperäiset soinnilliset klusiilit voivat edustua soinnillisina (ks. näytteitä 48-50), soinnittomina (ks. näytteitä 51 ja 52) tai kadota etenkin sananalkuisen konsonanttiyhtymän alkukomponenttina (53). Lisäksi klusiileista $g$ voi edustua $h$ :na (esim. 54: edustus tosin johtuu kirkkoslaavin ääntämyksestä), $d$ j:nä (esim. 55: edustus on karjalan sisäistä variaatiota) ja $b$ v:nä (56). 
(48) gošt'a (Suojärvi, Salmi, Suistamo, Korpiselkä) < ven. góst' 'vieras'

(49) besodat (kaikki pitäjät) < ven. beséda 'illanistujaiset'

(50) doroga dorga (Suojärvi, Salmi, Suistamo, Ilomantsi) < ven. doróga 'tie'

(51) puapo (Korpiselkä) < ven. bába 'akka, ämmä, mummo’

(52) ta (Suojärvi, Salmi, Impilahti) < ven. da 'ja, sekä, kyllä'

(53) riähky (Suojärvi) < ven. gréh 'synti'

(54) hospoti (Suojärvi, Suistamo, Korpiselkä, Ilomantsi) < ven. gospod' 'herra, jumala' tai kirkkosl. vok. gospodi '(oi) Herra!'

(55) jengat jenkat (kaikki pitäjät) < ven. den' $g i$ ' $r a h a t '$

(56) suovatta (Suojärvi, Salmi, Suistamo, Korpiselkä, Impilahti) < ven. subbóta 'lauantai'

Taulukot 5 ja 6 esittävät kaikki soinnillisten klusiilien vaihtelut sananalkuisessa sekä sanansisäisessä asemassa. Soinnilliset klusiilit korvautuvat muilla äänteillä harvoin. Etenkin ennen konsonanttia yleisin edustus on mallikoodia vastaava. Suomen kielen mukaista (Rapola 1966: 12, 16) mutta myös karjalan pohjoisimmille murteille tyypillistä (Zaikov 2006: 268) soinnitonta edustusta esiintyy etenkin läntisimmissä pitäjänmurteissa. Taulukon 5 mukaan varsinkaan $d$ :tä ei esiinny usein sanan alussa venäläisperäisissä sanoissa. Soinnilliset klusiilit paljastavat hyvin rajakarjalan venäläiskopioiden fonologian suomalaistumisen, sillä suomen alkuperäinen fonotaksi tukee soinnittomuutta.

Testasin eroja soinnillisten klusiilien edustuksessa soinnittomien klusiilien (ks. luku 6.2) tavoin: laskin taulukoiden 5 ja 6 kaikki soinnilliset ja sitten soinnittomat edustukset yhteen pitäjittäin, minkä jälkeen testasin pitäjien välisiä eroja Pearsonin $\chi^{2}$-testillä, joka osoittautui tilastollisesti merkitseväksi $(\mathrm{p}<0,001)$. Bonferroni-korjatussa post hoc -ristiinvertailussa selvisi, että soinnillisten klusiilien edustuksessa mahdollisista pitäjäpareista vain Suojärvi ja Salmi, Suojärvi ja Suistamo sekä Salmi ja Suistamo eivät eronneet toisistaan tilastollisesti merkitsevästi. Toisin sanoen soinnillisten klusiilien edustuksessa itäiset pitäjät eivät eroa toisistaan, kun taas läntiset pitäjät eroavat niin toisistaan kuin itäisistä pitäjistäkin. Näin voi päätellä, että suomi on vaikuttanut enemmän ja eri tavoin läntisten pitäjien soinnillisten klusiilien edustukseen. 


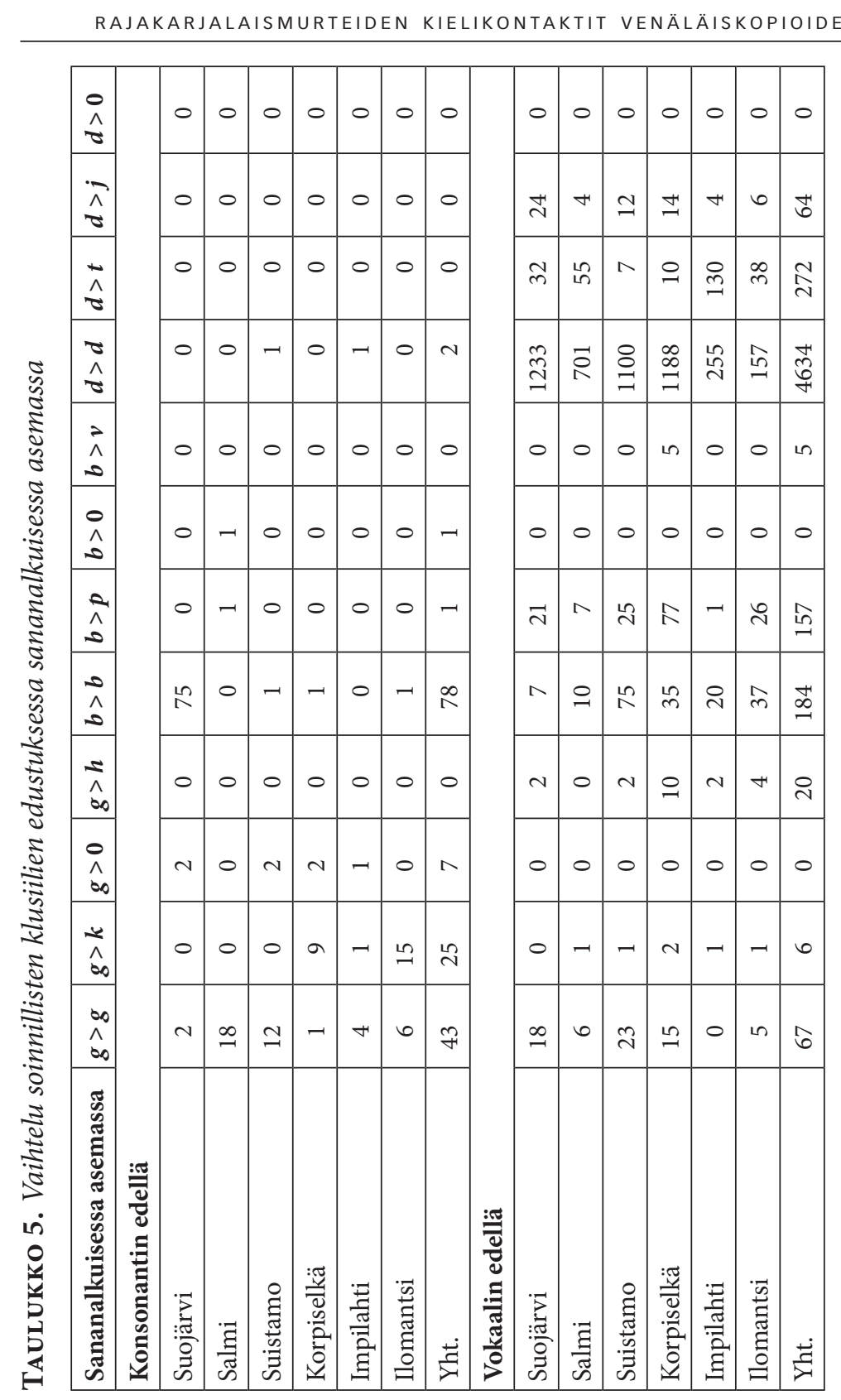




\begin{tabular}{|c|c|c|c|c|c|c|c|}
\hline $\begin{array}{l}0 \\
\hat{\sigma}\end{array}$ & $\infty$ & q & & & & & \\
\hline$\hat{\imath}$ & 0 & 0 & 0 & 0 & - & 0 & $\neg$ \\
\hline$\hat{\imath}$ & $\stackrel{\mathscr{2}}{\sim}$ & $\neg$ & 9 & in & $\Xi$ & ช్ & $\stackrel{\infty}{\triangleq}$ \\
\hline $\begin{array}{l}\tau \\
\hat{\tau}\end{array}$ & $\stackrel{\circ}{=}$ & $\stackrel{R}{1}$ & $\stackrel{g}{ \pm}$ & $\stackrel{\infty}{=}$ & in & 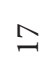 & $\overrightarrow{\mathrm{N}}$ \\
\hline $\begin{array}{l}\overrightarrow{\hat{n}} \\
\hat{0}\end{array}$ & $\infty$ & in & 으 & $\stackrel{0}{0}$ & $v$ & 0 & F \\
\hline $\begin{array}{l}0 \\
\hat{0}\end{array}$ & 0 & $\neg$ & 0 & 0 & $\neg$ & $\stackrel{10}{7}$ & 앙 \\
\hline 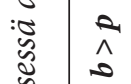 & 6 & $m$ & $\stackrel{\sim}{\sim}$ & $\stackrel{\infty}{\sim}$ & 6 & $\stackrel{2}{2}$ & tే \\
\hline$\hat{\Lambda}$ & 승 & $\stackrel{R}{1}$ & $\stackrel{\mathscr{Z}}{=}$ & 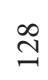 & নે & શે & $\begin{array}{l}\infty \\
\stackrel{+}{\alpha}\end{array}$ \\
\hline \begin{tabular}{l|l}
$\tilde{E}$ & $\hat{5}$ \\
$\tilde{\omega}$ & $\hat{0}$
\end{tabular} & $\infty$ & in & 가 & $\vec{v}$ & $N$ & 10 & $\approx$ \\
\hline 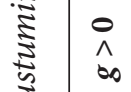 & 0 & 0 & - & 0 & 0 & 0 & - \\
\hline 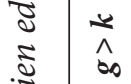 & $\psi$ & 0 & $\stackrel{\infty}{\infty}$ & I & $m$ & 10 & กิ \\
\hline $\begin{array}{l}\infty \\
\hat{\infty}\end{array}$ & 우 & 10 & $\infty$ & $\stackrel{n}{n}$ & $\Xi$ & 6 & 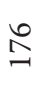 \\
\hline 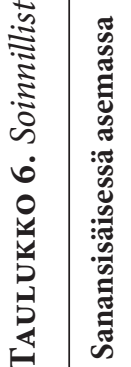 & 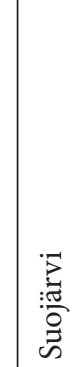 & 苂 & 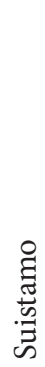 & 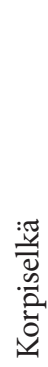 & 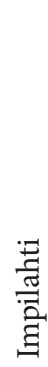 & $\begin{array}{l}\overline{5} \\
\text { 苂 } \\
\text { : } \\
0\end{array}$ & 苂 \\
\hline
\end{tabular}


RAJAKARJALAISMURTEIDEN KIELIKONTAKTIT VENÄLÄISKOPIOIDEN ...

\subsection{Affrikaatat}

Venäjän kielessä on kaksi affrikaattaa: liudentumaton soinnillinen dentaalinen affrikaatta $c$ sekä liudentunut soinniton palatoalveolaarinen affrikaatta $\check{c}$. Pyölin (1996: 194-196) mukaan venäjän $c$ :n kaltainen affrikaatta esiintyy karjalassa vain moderneissa venäläiskopioissa, kun taas venäjän $\check{c}$ :n kaltainen affrikaatta korvaa varsinkin vanhemmissa sanoissa venäjän kielen molemmat affrikaatat. Raja-Karjalan korpus edustaa vanhempaa karjalan kieltä, jossa esiintyy vain yhtä affrikaattaa, $\check{c}$ :tä. Samanlainen kahden affrikaatan yhteenlankeaminen ilmenee itämerensuomen vaikutuksesta myös pohjoisvenäläisissä murteissa (Myznikova 2014: 48). Yleensä venäläiskopioiden molemmat alkuperäiset affrikaatat $c$ ja $\check{c}$ edustuvat aineistossa $\check{c}$ :nä (Tavi 2015: 81), mikä ilmenee myös esimerkeistä 57 ja 58.

(57) päčči (kaikki pitäjät) < ven. peč' 'uuni'

(58) $\operatorname{sinččoh~(Korpiselkä)~<~ven.~senec~'eteinen,~porstua'~}$

Muita affrikaattojen edustuksia ovat suomen kielen vaikutuksesta tskonsonanttiyhtymä (59 ja 60) sekä läntisimmissä murteissa $s$ (61 ja 62).

(59) putsit < ven. bóčka 'tynnyri' (Ilomantsi)

(60) pätsii < ven. peč' 'uuni' (Ilomantsi)

(61) sikorjua (Suistamo), sigorjaskahvie (Korpiselkä), sikorjoa (Impilahti) < ven. cikórij 'sikuri',

(62) sassouna (Ilomantsi) < ven. časovn'a 'tsasouna'.

Affrikaatan korvautuminen suhusibilantilla sanan alussa on varsinkin karjalan kielen pohjoisimmille murteille tyypillinen piirre (Zaikov 1987: 24-25), mutta sitä esiintyy hieman myös rajakarjalaismurteissa (63).

(63) šasounat (Ilomantsi) < ven. časovn'a 'tsasouna'

Affrikaatat voivat myös kadota, mutta vain silloin, kun kyse on morfologisesta korvautumisesta. Esimerkissä 64 venäjän suffiksiksi hahmotettu -čka on korvattu karjalaisella johtimella $-k k a$. 
(64) pualikka; pual'ikka (Suojärvi, Ilomantsi; Suistamo, Korpiselkä) < ven. paločka 'keppi'

Affrikaattojen korvautuminen toisilla äänteillä on aineistossa kuitenkin erittäin harvinaista. Taulukko 7 esittää affrikaattojen edustajien frekvenssit sananalkuisessa ja -sisäisessä asemassa Raja-Karjalan korpuksessa.

TAULUкко 7. Affrikaattojen edustajien frekvenssit sananalkuisessa ja -sisäisessä asemassa pitäjittäin

\begin{tabular}{|l|r|r|r|r|r|r|r|r|r|r|r|r|}
\hline & $\boldsymbol{c}>\check{\boldsymbol{c}}$ & $\boldsymbol{c}>\boldsymbol{t s}$ & $\boldsymbol{c}>\boldsymbol{s}$ & $\boldsymbol{c}>\mathbf{0}$ & $\check{\boldsymbol{c}}>\check{\boldsymbol{c}}$ & $\check{\boldsymbol{c}}>\boldsymbol{t} \check{\boldsymbol{s}}$ & \multicolumn{1}{|c|}{$>\boldsymbol{t} \boldsymbol{s}$} & $\check{\boldsymbol{c}}>\check{\boldsymbol{s}}$ & $\check{\boldsymbol{c}}>\boldsymbol{s}$ & $\check{\boldsymbol{c}}>\mathbf{0}$ \\
\hline Sananalkuisessa asemassa \\
\hline Suojärvi & 2 & 0 & 1 & 0 & 20 & 0 & 0 & 0 & 0 & 0 \\
\hline Salmi & 2 & 1 & 0 & 0 & 41 & 0 & 0 & 0 & 0 & 0 \\
\hline Suistamo & 0 & 0 & 2 & 0 & 44 & 0 & 0 & 0 & 0 & 0 \\
\hline Korpiselkä & 0 & 0 & 3 & 0 & 79 & 0 & 2 & 0 & 0 & 0 \\
\hline Impilahti & 0 & 0 & 2 & 0 & 26 & 0 & 0 & 0 & 0 & 0 \\
\hline Ilomantsi & 0 & 0 & 0 & 0 & 24 & 0 & 0 & 4 & 6 & 0 \\
\hline Yht. & 4 & 1 & 8 & 0 & 234 & 0 & 2 & 4 & 6 & 0 \\
\hline Sanansisäisessä asemassa & & & & & & & \\
\hline Suojärvi & 15 & 0 & 0 & 0 & 59 & 0 & 0 & 0 & 0 & 6 \\
\hline Salmi & 26 & 0 & 0 & 0 & 28 & 0 & 1 & 0 & 0 & 0 \\
\hline Suistamo & 52 & 1 & 0 & 0 & 114 & 1 & 0 & 0 & 0 & 4 \\
\hline Korpiselkä & 61 & 1 & 1 & 0 & 95 & 0 & 0 & 0 & 0 & 8 \\
\hline Impilahti & 12 & 0 & 0 & 0 & 13 & 0 & 0 & 0 & 0 & 0 \\
\hline Ilomantsi & 26 & 0 & 1 & 4 & 35 & 0 & 5 & 0 & 0 & 4 \\
\hline Yht. & 192 & 2 & 2 & 4 & 344 & 1 & 6 & 0 & 0 & 22 \\
\hline
\end{tabular}

Kuten taulukosta 7 käy ilmi, venäjän affrikaatat edustuvat affrikaatta $\check{c}$ :nä kaikissa pitäjänmurteissa lähes aina. Näin myöskään tilastollinen tarkastelu ei ole tarpeen. Affrikaatan säilyminen koskee sekä sanansisäistä (65 ja 66) että sananalkuista (67 ja 68) asemaa. 
RAJAKARJALAISMURTEIDEN KIELIKONTAKTIT VENÄLÄISKOPIOIDEN ...

(65) staučas (Suojärvi, Salmi) < ven. stavec 'puusta tai savesta tehty kulho tai tuoppi'

(66) harčevoim (Suojärvi), keskiharččovoi (Suistamo), harčovoi (Korpiselkä), harččavois (Impilahti), harčovassa (Ilomantsi) < ven. harčevn'a 'ruokala, majatalo' (ks. $e>o$-muutoksesta luku 3.2)

(67) čiepit (Suojärvi, Salmi) < ven. cép' 'kettinki, ketju(t), vitjat'

(68) čainiekat (Suojärvi), čainik (Salmi), čain'iekkaa (Korpiselkä) < ven. čajnik 'teepannu'

Taulukkoon 7 ei ole laskettu mukaan sellaisia venäläisperäisiä sanoja, joiden alussa on sibilantin ja affrikaatan muodostama äänneyhtymä, sillä se ei äänny venäjässä affrikaattana. Rajakarjalaisaineistossa venäläisperäisten sanojen sibilanttien muodostama yhtymä kuitekin äännetään yleensä affrikaatta $\check{c}:$ nä (69).

(69) čotta (Suojärvi), čottua (Salmi), kappalečotal (Suistamo), kuormačotalla (Korpiselkä), čottoa (Impilahti), net' äličotalla (Ilomantsi) < ven. sčjot 'lasku'

Affrikaatta $\check{c}$ on vahvasti karjalainen piirre, sillä se on säilynyt lähes kaikissa aineiston venäläiskopioissa. Affrikaattaa esiintyy omaperäisissäkin sanoissa, joissa venäläiskopioiden tapaan $\check{c}$ vaihtelee esimerkiksi sibilantin $s$ kanssa, kuten esimerkiksi 'somaa' merkitsevissä saneissa čoma (Salmi, Suistamo, Korpiselkä) ja soma (Korpiselkä). Aineistossa esiintyy siis hieman suomen mukaista edustusta, mutta ne ovat poikkeuksia; yleensä affrikaatta $\check{c}$ on säilynyt muusta rajakarjalasta poikkeavassa Ilomantsin murteessakin.

\subsection{Sibilantit}

Venäjän sibilantteihin kuuluvat liudentumattomat dentaaliset $s$ (soinniton) ja $z$ (soinnillinen) sekä soinniton palatoalveolaarinen $\breve{s}$ ja sen soinnillinen vastine $\check{z}$. Venäjässä on myös liudentunut soinniton pitkä palatoalveolaarinen sibilantti $/ \check{s} \check{c} /$, jota vastaa venäjän ortografiassa $m$. (Ks. esim. Nikunlassi 2002: 80-84.) Karjalan kielen sibilanttijärjestelmä on muuttunut paljolti venäjän kielen kaltaiseksi, kun ilmeisesti 
venäjän vaikutuksesta on omaksuttu sekä soinnillisuus- että dentaalisten ja palatoalveolaaristen sibilanttien oppositio (Turunen 1973: 84-85).

Aineiston venäläisperäisten sanojen sibilantit edustuvat venäjän alkuperäisiä sibilantteja vastaavina, vaikka korvautumisstrategioissa on joitain poikkeuksiakin. Esimerkiksi Salmin murteessa sibilantit edustuva yleensä alkuperäisiä vastaavina, mutta voivat myös korvautua seuraavasti: $s>s ; z>s, z ; \check{s}>\check{s}$; $\check{z}>z, \check{z} ; \check{s} \check{c}>\check{s}$ (Kujola 1910: 65-66; Tavi 2015: 86-94). Kujola (mt.) erottelee myös liudentuneet ja liudentumattomat sibilantit toisistaan, mitä tässä tutkimuksessa ei tehdä. Käsittelen tässä sekä sanansisäisen että -alkuisen aseman sibilantit yhdessä, sillä asema ei vaikuta olennaisesti sibilanttien edustukseen. Sibilanttien edustusta kuvaavassa taulukossa 8 ei ole esitetty venäjän sibilanttia $\check{s} c$, koska sitä ei sellaisenaan esiinny karjalassa ja se on venäläiskopioissa äänteenä harvinainen. Tavallisimmin äänne korvataan karjalassa š:llä (Kujola 1910: 65-66) ja näin on myös rajakarjalaisaineistossa (70).

(70) brikaššikat < ven. prikázčik 'metsätöissä tai uitossa ylin työnjohtaja, uittopäällikkö’ (Suojärvi)

Sanassa prikázčik esiintyvä $z c ̌$ ääntyy /ščl:nä venäjässä, mutta se on korvautunut Suojärven murteessa geminaatta-š:llä.

Muut edustukset käyvät ilmi taulukosta 8 . Ensiksi taulukossa 8 on säilyneiden sibilanttien edustuksen taajuus ja sen vieressä frekvenssi muista korvautumisista. Ruutu on harmaa silloin, kun sibilantit useammin säilyvät kuin korvautuvat (esimerkiksi toisella sibilantilla). Harmaa väri kuvaakin sibilanttien kompleksisten ominaisuuksien säilymisen jatkumonomaisuutta pitäjänmurteittain.

Pitäjien välisten erojen tilastollinen vertailu sibilanttien edustuksessa tukee jatkumomaisuutta. Laskin kunkin sibilantin säilyneet edustukset yhteen sekä kunkin sibilantin muut edustukset yhteen ja vertailin ryhmien eroja pitäänmurteiden kesken. Pearsonin $\chi^{2}$-testin tulos osoittautui tilastollisesti merkitseväksi $(\mathrm{p}<0,001)$. Bonferroni-korjatussa post hoc -ristiinvertailussa paljastui tilastollisesti merkitsevä ero $(\mathrm{p}<0,05)$ muiden mahdollisten pitäjäparien paitsi Suojärven ja Salmin, Salmin 
ja Suistamon, Suistamon ja Korpiselän, Suistamon ja Impilahden sekä Korpiselän ja Impilahden välillä eli eroja ei ole naapuripitäjien kesken.

TAULUкко 8. Vaihtelu sibilanttien edustuksessa

\begin{tabular}{|c|c|c|c|c|c|c|c|c|}
\hline & $s>s$ & $\begin{array}{c}s> \\
\text { muu }\end{array}$ & $\check{\boldsymbol{s}}>\check{\boldsymbol{s}}$ & $\begin{array}{l}\check{\boldsymbol{s}}> \\
\text { muu }\end{array}$ & $z>z$ & $\begin{array}{c}z> \\
\text { muu }\end{array}$ & $\check{z}>\check{z}$ & $\begin{array}{c}\check{z}> \\
\text { muu }\end{array}$ \\
\hline Suojärvi & 130 & 34 & 37 & 10 & 52 & 20 & 93 & 22 \\
\hline Salmi & 50 & 21 & 7 & 6 & 37 & 23 & 51 & 9 \\
\hline Suistamo & 196 & 44 & 31 & 8 & 50 & 23 & 42 & 101 \\
\hline Korpiselkä & 229 & 67 & 37 & 27 & 38 & 98 & 15 & 56 \\
\hline Impilahti & 78 & 18 & 0 & 5 & 1 & 44 & 7 & 5 \\
\hline Ilomantsi & 77 & 12 & 2 & 5 & 16 & 86 & 3 & 49 \\
\hline Yht. & 760 & 196 & 114 & 61 & 194 & 294 & 211 & 242 \\
\hline
\end{tabular}

Taulukosta 8 ilmenee, että Raja-Karjalan korpuksen venäläisperäisten sanojen sibilanteista ainoastaan $s$ on säilynyt kaikissa pitäjissä sekä sanansisäisessä (71) että sananalkuisessa (72) asemassa.

(71) bes'odoi, bes'odat, besodaa, besota, bessodat (kaikki pitäjät) < ven. beséda 'juttelu; illanistujaiset'

(72) stola, stolat, stolas ja stolan (Suojärvi, Salmi, Suistamo, Korpiselkä, Ilomantsi) < ven. stól 'pöytä'

Soinnillinen $z$ taas on säilynyt enemmän kuin korvautunut toisella äänteellä vain Suojärven, Salmin ja Suistamon pitäjänmurteissa (73), kun esimerkiksi Impilahden murteessa $z$ on korvautunut ja korvautumisessa on vaihtelua saman lekseemin saneiden kesken (74). š puolestaan on säilynyt Suojärven, Salmin, Suistamon ja Korpiselän murteissa (ks. taulukkoa 8 sekä näytettä 75). Läntisemmissä Impilahdessa ja Ilomantsissa š korvautuu useammin jollain muulla sibilantilla, esimerkiksi s:llä (76).

(73) pruazniekka pruaznikka (Suojärvi, Salmi, Suistamo) < ven. prázdnik 'juhla'

(74) priusa priuša priužakse (Impilahti) < ven. priuz 'riusa, solmuvarsta' 
(75) šuapku < ven. šápka 'hattu' (Korpiselkä)

(76) masina < ven. mašina 'kone, auto' (Ilomantsi)

$\check{z}$ on aineiston venäläiskopioiden sibilanteista suomen kieleen nähden kompleksisin, sillä siinä on suomen kielen konsonanteille epätyypilliset piirteet sointi ja suhu. Äänne onkin alkuperäistä vastaava vain itäisimmissä Suojärven ja Salmin (ks. taulukkoa 8 ja näytettä 77) murteissa sekä Impilahden murteessa, joskin jälkimmäisestä on hyvin vähän esiintymiä päätelmien teon kannalta (ks. taulukkoa 8). Läntisissä pitäjissä $z$ :n voi korvata esimerkiksi $s(78)$.

(77) žiivatat (Salmi) < ven. život 'eläin'

(78) siivatta (Ilomantsi) < ven. život 'eläin'

Kaikista tarkastelluista konsonanteista sibilanteista käy parhaiten ilmi suomen kielen vaikutus rajakarjalaismurteisiin. Murteiden venäläisvaikutuksen jatkumonomaisuus ilmenee sibilanteista siten, että alkuperäinen $s$ edustuu $s$ :nä kaikissa pitäjissä ja piirteiltään kompleksisin $\check{z}$ edustuu $\check{z}:$ nä vain itäisimmissä pitäjänmurteissa. Myös tilastollinen tarkastelu tukee tätä havaintoa. Sibilanttien suomen kieleen kuulumattomista äännepiirteistä sointi vaikuttaisi säilyvän huonommin kuin suhu.

\section{Lopuksi}

Tässä tutkimuksessa tarkastelin Raja-Karjalan kielikontakteja suomeen ja venäjään venäläiskopioiden taajuutta ja fonologiaa vertailemalla. Tutkimuskysymyksinä oli, onko Raja-Karjalan pitäjänmurteiden välillä eroja venäläiskopioiden määrässä ja fonologiassa, kuinka suomen kieli on vaikuttanut venäläiskopioiden fonologiaan ja mitä kopioiden fonologian perusteella voidaan päätellä Raja-Karjalan kontakteista venäjään. Tutkimustulokset osoittivat, että sanatasolla venäläisvaikutus on murteissa jatkumon kaltaista ja heikkenee pitäjä pitäjältä länteen päin ja että pitäjänmurteiden välillä on tilastollisesti merkitsevät erot kopioiden määrissä. 
RAJAKARJALAISMURTEIDEN KIELIKONTAKTIT VENÄLÄISKOPIOIDEN ...

Myös fonologiassa on eroja pitäjänmurteiden välillä: klusiilien soinnillisuus ja sibilantit ovat sellaisia piirteitä, joiden avulla rajakarjalaismurteiden kontakteja sekä suomeen että venäjään pystyy tulkitsemaan parhaiten, ja erot etenkin läntisimpien ja itäisimpien pitäjien välillä olivat tilastollisesti merkitsevät. Suomalaisvaikutusta osoittaa soinnillisten klusiilien soinniton edustus, venäläis-karjalaisen kieliliiton vaikutusta puolestaan soinnittomien klusiilien edustus soinnillisina. Lisäksi sibilanttien ominaisuuksien kompleksisuus vähenee piirre kerrallaan pitäjänmurteittain idästä länteen. Konsonanteista vain affrikaatta on sellainen äänne, joka on säilynyt lähes kaikissa venäläiskopioissa suomen kielen vaikutuksesta huolimatta. Itäisten ja läntisten pitäjänmurteiden välillä ei ole eroja affrikaatan edustuksessa. Tulokset vastasivat oletuksia, mutta suomen vaikutus ei ollut etenkään affrikaatan osalta oletetun voimakasta läntisimmissä pitäjissä.

Kun venäjä on vaikuttanut karjalan konsonantiston kehitykseen, itämerensuomi on taas vaikuttanut pohjoisvenäläisten murteiden vokaalistoon. Rajakarjalaisaineiston venäläiskopioiden lyhyet sekä jälkitavujen vokaalit vastaavat joko yleis- tai pohjoisvenäläistä varianttia. Painollisen ensitavun vokaalit taas pidentyvät ja diftongiutuvat, mikä on kieliliitonkin kannalta vahva piirre. Joitain jälkiä suomen kielen kontaktista on havaittavissa, mutta vokaalit vastaavat pääsääntöisesti yleiskarjalaista fonotaksia. Vokaalien fonologinen tarkastelu pohjautui venäjän sanapainoon, sillä venäjässä sanapaino vaikuttaa vokaalien ääntämykseen ja siten kopiointiin.

Korpus- eli myös käyttöpohjaisuus osoittautui toimivaksi metodologiseksi kehykseksi: sen puitteissa aineiston kokoamista, läpi käymistä ja lopulta analyysiä on arvioitava niin teoreettisen kehyksen kannalta kuin tilastollisestikin. Tällainen metodologia tuo esiin myös fonologisessa analyysissä keskeisimmät piirteet. Tulokset tukevat aiempia tutkimuksia, mutta myös antavat uutta tietoa Suomessa puhuttujen rajakarjalaismurteiden siteestä etenkin karjalan ja pohjoisvenäläisten murteiden muodostamaan kieliliittoon sekä suomen kielen vaikutuksesta karjalan kehitykseen. Etenkin maantieteellä on merkitystä venäläisperäisyyksien 
esiintymisessä, eikä niinkään sillä, mitä murretta, eli livvin- vai eteläkarjalaa, alueella oletetaan puhutun. Tulevaisuudessa olisi hyödyllistä tarkastella lisää suomen ja venäjän vaikutuksen kohtaamista Suomessa puhuttavassa karjalassa sanaston karttumisen ja kartuttamisen näkökulmasta.

\section{Kiitokset}

Kiitän Lauri Tavia tutkimusta suuresti hyödyttäneen kieliteknologisen asiantuntemuksen jakamisesta. Lisäksi kiitän Rogier Bloklandia hyvistä lähdeneuvoista sekä kahta anonyymia arvioijaa käsikirjoituksen viimeistelyssä auttaneista kommenteista. Artikkeli on saanut taloudellista tukea Itä-Suomen yliopistolta, ja tutkimus liittyy hankkeeseen "Muutto ja kielellinen eriytyminen: karjala Tverissä ja Suomessa” (SA 314848).

\section{Lähteet}

Ahtia, Edvard Vilhelm 1938. Karjalan kielioppi. Äänne- ja sanaoppi ['Grammar of Karelian. Phonology and lexicology']. Helsinki: Kotimaisten kielten keskus. http://kaino.kotus.fi/digitointi/pdf/Ahtian_sana__ja_aanneoppi.pdf (26.9.2018).

Backus, Ad 2010. The role of codeswitching, loan translation and interference in the emergence of an immigrant variety of Turkish. - Working Papers in Corpus-based Linguistics and Language Education 5, 225-241.

Backus, Ad 2014. A usage-based approach to borrowability. - Eline Zenner, Gitte Kristiansen (Eds.), New Perspectives on Lexical Borrowing. Onomasiological, Methodological and Phraseological Innovations. Boston: Mouton De Gruyter, 19-39.

Boersma, Paul, David Weenink 2017. Praat: doing phonetics by computer [Computer program]. Version 6.0.28. http://www.praat.org/ (21.4.2017).

Bondarko, Liya 2009. Short description of Russian sound system. - Riikka Ullakonoja (Ed.), Phonetics of Russian and Finnish. General Description of Phonetic Systems. Experimental Studies on Spontaneous and Read-aloud Speech. Frankfurt am Main: Peter Lang, 23-36.

Cubberley, Paul 2002. Russian. A Linguistic Introduction. Cambridge: Cambridge University Press. 
RAJAKARJALAISMURTEIDEN KIELIKONTAKTIT VENÄLÄISKOPIOIDEN ...

Fife, Dustin 2017. Fifer: A Biostatisticians Toolbox for Various Activities, Including Plotting, Data Cleanup, and Data Analysis. R package version 1.1. https://CRAN.R-project.org/package=fifer (23.1.2018).

FINKA = FINKA-hankkeen sivusto. https://www.uef.fi/en/web/finka (23.1.2018).

Fortson, Benjamin W. 2010. Indo-European Language and Culture. An Introduction. Second edition. Singapore: Wiley-Blackwell.

Genetz, Arvid 1884. Tutkimus Aunuksen kielestä. Kielennäytteitä, sanakirja ja kielioppi ['Study on the Olonets language. Language samples, dictionary and grammar']. Helsinki: Suomalaisen Kirjallisuuden Seura.

Gries, Stefan Th., Anatol Stefanowitsch 2006. Cluster analysis and the identification of collexeme classes. - Sally Rice, John Newman (Eds.). Empirical and Experimental Methods in Cognitive/Functional Research. CSLI Publications, 73-90.

Hämynen, Tapio 1994. Mikä Karjala? - Tapio Hämynen (Toim.), Kahden Karjalan välillä. Kahden riikin riitamaalla. Studia Carelica Humanistica 5. Joensuu: Joensuun yliopiston humanistinen tiedekunta, 17-27.

Iivonen, Antti 2009. Finnish sentence accent and intonation. - Riikka Ullakonoja (Ed.), Phonetics of Russian and Finnish. General Description of Phonetic Systems. Experimental Studies on Spontaneous and Read-aloud Speech. Frankfurt am Main: Peter Lang, 67-75.

Itkonen, Terho 1968. Itäsuomalaisen liudennuksen fonologinen paradoksi ['The phonological paradox of the Eastern Finnish palatalisation']. - FennoUgrica. Juhlakirja Lauri Postin kuusikymmenvuotispäiväksi 17.3.1968. Suomalais-Ugrilaisen Seuran Toimituksia 145. Helsinki: Suomalais-Ugrilainen Seura, 76-103.

Jeskanen, Matti 2005. Karjalan kieli ja karjalankieliset Suomessa ['Karelian language and Karelian speakers in Finland']. - Marjatta Palander, Anne-Maria Nupponen (Toim.), Monenlaiset karjalaiset. Suomen karjalaisten kielellinen identiteetti. Studia Carelica Humanistica 20. Joensuu: Joensuun yliopiston humanistinen tiedekunta, 215-285.

Johanson, Lars 2002. Contact-induced change in a code-copying framework. Mari C. Jones, Edith Esch (Eds.), Language Change. The Interplay of Internal, External and Extra-Linguistic Factors. Berlin, New York: Mouton de Gruyter, 286-313.

Kalima, Jalo 1952. Slaavilaisperäinen sanastomme. Tutkimus itämerensuomalaisten kielten slaavilaisista lainoista. SKS:n toimituksia 234. Helsinki: Suomalaisen Kirjallisuuden Seura. 
KKS = Karjalan kielen sanakirja ['Dictionary of Karelian']. Kotimaisten kielten tutkimuskeskuksen verkkojulkaisuja 18. Helsinki, 2009. http://kaino.kotus.fi/ cgi-bin/kks/kks_etusivu.cgi (15.12.2017).

Kok, Maria 2016. Varjon kieliopillistuminen. Itse-sanan paradigman rakenne ja merkityksenkehitys itäisessä itämerensuomessa ['Grammaticalisation of shadow. The paradigm structure and the development of the meaning of the word 'itse' ('self') in the eastern Finnic languages']. Publications of the University of Eastern Finland. Dissertation in Education, Humanities, and Theology 83. Joensuu: University of Eastern Finland.

Kuujo, Erkki 1963. Raja-Karjala Ruotsin vallan alla ['Border Karelia during Swedish rule']. Joensuu: Karjalaisen Kulttuurin Edistamissäätiö.

Kujola, Joh. 1910. Äänneopillinen tutkimus Salmin murteesta ['A phonological study on the dialect of Salmi']. Helsinki: Suomalaisen Kirjallisuuden Seura.

Leskinen, Eino 1934. Karjalan kielen näytteitä II. Aunuksen ja Raja-Karjalan murteita ['Samples of the Karelian Language II. Dialects of Olonets and Border Karelia']. SKS:n toimituksia 193. Helsinki: Suomalaisen Kirjallisuuden Seura.

Leskinen, Heikki 1998. Karjala ja karjalaiset kielentutkimuksen näkökulmasta ['Karelian and the Karelians from the viewpoint of linguistics']. - Pekka Nevalainen, Hannes Sihvo (Toim.), Karjala: historia, kansa, kulttuuri. SKS:n toimituksia 705. Helsinki: Suomalaisen Kirjallisuuden Seura, 352382.

McEnery, Tony, Richard Xiao, Yukio Tono 2006. Corpus-Based Language Studies. An Advanced Resource Book. London: Routledge.

Myznikova, Ja. V. 2014. Russko-pribaltijsko-finskie jazykovye kontakty i ih otraženie v oblasti dialektnogo sintaksisa. Sankt-Peterburg: Nestor-Istorija.

Nikunlassi, Ahti 2002. Johdatus venäjän kieleen ja sen tutkimukseen ['Introduction to Russian language and its research']. Helsinki: Finn Lectura.

Ojansuu, Heikki 1905. Karjalan äänneoppi ['Karelian phonetics']. Helsinki: Suomalaisen Kirjallisuuden Seura.

Ojansuu, Heikki 1918. Karjala-aunuksen äännehistoria ['Sound history of Karelian-Olonetsian']. Helsinki: Suomalaisen Kirjallisuuden Seura.

Orlova, V. G. 1970. Izmenenije /e/ v /o/. - V. G. Orlova (Otv. Red.), Obrazovanije severnorusskogo narečija i srednerusskih govorov po materialam lingvističeskoj geografij. Moskva: Izdatel'stvo Nauka, 22-23.

Pyöli, Raija 1996. Venäläistyvä aunuksenkarjala. Kielenulkoiset ja -sisäiset indikaattorit kielenvaihtotilanteessa ['Olonets Karelian under the pressure of 
RAJAKARJALAISMURTEIDEN KIELIKONTAKTIT VENÄLÄISKOPIOIDEN ...

Russian. Extralinguistic and linguistic indicators in a state of language shift']. Joensuun yliopiston humanistisia julkaisuja 18. Joensuu: Joensuun Yliopisto.

Pyöli, Raija 2013. Rajakarjalaiset ja muuttuva identiteetti ['Border-Karelians and changing identity']. - Pekka Suutari (Toim.), Karjala-kuvaa rakentamassa. SKS:n toimituksia 1389. Helsinki: Suomalaisen Kirjallisuuden Seura, 159181.

Raja-Karjalan korpus ['Border Karelian corpus']. Noin 119 tuntia Raja-Karjalan murreäänitteitä litteroituna. FINKA-tutkimushanke 2011-2014. Itä-Suomen yliopisto. http://www.uef.fi/en/web/finka (26.9.2018).

Rapola, Martti 1966. Suomen kielen äännehistorian luennot ['Lectures on the phonological history of Finnish']. SKS:n toimituksia 283. Helsinki: Suomalaisen Kirjallisuuden Seura.

Ravila, Paavo 1973. Zur Kritik der mordwinischen Substrathypothese des russischen Akanje. - Commentationes Fenno-Ugricae in honorem Erkki Itkonen sexagenarii. Suomalais-Ugrilaisen Seuran toimituksia 150. Helsinki: Suomalais-Ugrilainen Seura, 296-310.

R Core Team 2016. R: A Language and Environment for Statistical Computing. R Foundation for Statistical Computing, Vienna, Austria. https:// www.R-project.org/ (23.1.2018).

Ruoppila, Veikko 1986. Venäläisperäistä sanastoa suomen murteissa. Suomi 136. Helsinki: Suomalaisen Kirjallisuuden Seura.

Saksa, Aleksander 1994. Rautakautinen Karjala. Karjalan synty. - Tapio Hämynen (Toim.), Kahden Karjalan välillä, kahden Riikin riitamaalla. Studia Carelica Humanistica 5. Joensuu: Joensuun yliopiston humanistinen tiedekunta, 29-46.

Sarhimaa, Anneli 1995. Karjalan kansat ja kielet kontakteissa. Asutushistoriallista taustaa ja lingvistisiä seurauksia ['Karelian peoples and languages in contact: settlement history and linguistic consequences']. - Virittäjä 99 (2), 191-223.

Sarhimaa, Anneli 2017. Vaietut ja vaiennetut. Karjalankieliset karjalaiset Suomessa. Tietolipas 256. Helsinki: Suomalaisen Kirjallisuuden Seura.

Scott, Mike 2012. WordSmith Tools version 6. Stroud: Lexical Analysis Software.

Tavi, Susanna 2015. Rajakarjalaismurteiden venäläiset lainasanat ['Russian loanwords in Border Karelian dialects']. Pro gradu -tutkielma. Itä-Suomen yliopisto, suomen kieli. http://urn.fi/urn:nbn:fi:uef-20160039

Turunen, Aimo 1965. Suojärven murre ['The dialect of Suojärvi']. - Lauri Pelkonen (Toim.), Suojärvi I. Pieksämäki: Suosäätiö, 21-38. 
Turunen, Aimo 1973. Raja-Karjalan murteet ja vepsän kieli ['Border Karelian dialects and Veps']. - Hannes Sihvo (Toim.), Karjala. Idän ja lännen silta. Kalevalaseuran vuosikirja 53. Porvoo: WSOY, 83-94.

Uusitupa, Milla 2017. Rajakarjalaismurteiden avoimet persoonaviittaukset ['Open person constructions in Border Karelian dialects']. Publications of the University of Eastern Finland. Dissertations in Education, Humanities, and Theology 117. Joensuu: University of Eastern Finland.

Uusitupa, Milla, Vesa Koivisto, Marjatta Palander 2017. Raja-Karjalan murteet ja raja-alueiden kielimuotojen nimitykset ['Border Karelian dialects and the terminology of Karelian borderlands' language variaties']. - Virittäjä 121 (1), 67-106.

VISK = Hakulinen, Auli, Maria Vilkuna, Riitta Korhonen, Vesa Koivisto, Tarja Riitta Heinonen, Irja Alho 2008. Ison suomen kieliopin verkkoversio ['Comprehensive grammar of Finnish']. http://scripta.kotus.fi/visk (26.2.2018).

Zaikov, Pekka 1987. Karjalan kielen murreoppia. Opetusmoniste. Petroskoi: VSNT O.W. Kuusiselle nimetty Petroskoin valtionyliopisto.

Zaikov, Pekka 2006. "Vuokkiniemies paissah puhasta karjalua". Karjalan kieli ja Vuokkiniemen murre ['Karelian and the dialect of Vuokkiniemi']. - Kai Paajaste (Toim.), Tupenkolahuttajien mailla: Vuokkiniemi esihistoriasta toiseen maailmansotaan. Mustasaari: Vuokkiniemi-seura, 264-290. 


\title{
Language contacts of Border Karelian dialects in the light of frequency and phonology of Russian copies
}

\author{
SUSANNA TAVI \\ University of Eastern Finland
}

This article presents a corpus- and usage-based study on the contacts of Border Karelian dialects from the point of view of Russian-origin words (copies, in Lars Johanson's terminology) and their phonological features. The aim of the study is to describe the contacts between Border Karelian, i.e. partly mixed Southern and Olonets Karelian dialects, Finnish and Russian by comparing the dialects of six parishes as reflected in the synchronic spoken-language corpus of Border Karelian.

The dialects of Border Karelia were spoken until World War II in the easternmost part of Finland. They are distinguished from other varieties of Karelian by the strong influence of Finnish; this began already in the 17th century, and strengthened after 1944, when Border Karelia was ceded to the Soviet Union and its inhabitants were resettled in other parts of Finland. The material of the corpus of Border Karelian has been recorded after the resettlement, from informants who no longer lived in their original home regions.

The study focuses on Russian copies that are a conventionalized part of Karelian and do not occur in Finnish. The statistical tests indicated that differences in the frequencies of these words are statistically significant between the original parish dialects; the easternmost dialect has the most Russian copies, and the number of copies decreases from east to west with each successive parish. The results confirm the general hypothesis of Finnic language varieties as a continuum, on which the effect of Russian gradually grows as one moves east. The continuum is geographical, and thus Olonets Karelian dialects do not have more Russian copies than Southern Karelian dialects, opposite to the assumptions. Accordingly, the results of the phonological analysis show that features which deviate from the phonotactics of Finnish are most frequent in the easternmost dialects and rarer in the west. The features of vowels indicate that all 
Border Karelian dialects have had intense contact with both North Russian dialects and Standard Russian.

In conclusion, the lexical and phonological impact of Russian on Border Karelian, increasing gradually from west to east, can be detected in the speech of Border Karelian informants even two decades after their resettlement to a Finnish-speaking environment.

Keywords: contact linguistics; corpus linguistics; copying; lexicon; phonology; Border-Karelian; Finnish; Russian

\section{Susanna Tavi}

Itä-Suomen yliopiston humanistinen osasto

Suomen kieli ja kulttuuritieteet

PL 111

FI-80101 Joensuu, Finland

susanna.tavi@uef.fi 